$\underline{\text { Review Article }}$

\title{
RECENT DEVELOPMENTS AND MULTIPLE BIOLOGICAL ACTIVITIES AVAILABLE WITH 1, 8- NAPHTHYRIDINE DERIVATIVES: A REVIEW
}

\author{
VINOD KUMAR GURJAR, DILIPKUMAR PAL*
}

Department of Pharmaceutical Sciences, Guru Ghasidas Vishwavidyalaya (A Central University), Koni, Bilaspur 495009, C. G., India Email: drdilip2003@gmail.com

Received: 23 Oct 2018 Revised and Accepted: 23 Nov 2018

\begin{abstract}
Within the wide range of nitrogen-containing heterocyclic compounds, the derivatives of 1,8-naphthyridine (NPTR) have gained a rising interest due to their reported versatile biological activities. The derivatives of NPTR scaffold are found to invite special interest from researchers nowadays on the significance of their manifestations of multiple attractive pharmacological activities which establish them as an effective and versatile tool in pharmaceutical chemistry and drug discovery. The diverse biological activities mainly include anti-inflammatory, antimicrobial, antiviral, anticancer, antihypertensive and analgesic activities. Novel NPTR scaffold has emerged its potency to treat neurological diseases like depression and Alzheimer's disease. Further these agents possess different inhibitory activities, such as anti-HIV, anti-osteoporotic, $\alpha_{v} \beta_{3}$ antagonism, antimalarial, platelet aggregation, anti-oxidant, anti-allergic, gastric antisecretory, anticonvulsant, epidermal growth factor receptor (EGFR) inhibition, protein kinase inhibition, ionotropic properties, $\beta_{3}$ antagonism, phosphodiesterase 4 (PDE 4) inhibitions, adenosine receptor agonistic activity, adrenoceptors antagonism and DNA stabilizing activity, etc. In this review, we highlight the updates of different 1,8-naphthyridine derivatives and explain the key data available in the context of various biological activities of NPTR derivatives available from the literature. This may direct opportunity in researches in the synthesis of novel medicinal agents and the development of new heterocycles for modification of existing biological actions as well as evaluation of other possible pharmacological activities.
\end{abstract}

Keywords: 1,8-Naphthyridine (NPTR), Quinolone, Antimicrobial activity, Anticancer activity, Antitumor, Anti-inflammatory activity, Antimalarial antihypertensive, Antiplatelet activity, $\alpha v \beta 3$ antagonist

(C) 2019 The Authors. Published by Innovare Academic Sciences Pvt Ltd. This is an open access article under the CC BY license (http://creativecommons.org/licenses/by/4.0/) DOI: http://dx.doi.org/10.22159/ijpps.2019v11i1.30429

\section{INTRODUCTION}

Nowadays, researchers are concentrating interests towards the introduction of novel and safe therapeutic agents for getting medical significance [1]. The nitrogen-containing heterocycles are the major class of chemical compounds in therapeutic uses. Naphthyridine is one of such heterocycle. The name naphthyridine is often known to the fused-ring system, which is formed by the fusion of two pyridine rings with two neighboring carbon atoms, and every ring system having only a single nitrogen atom. This name was first recommended by A. Reissert, who prepared the first series of naphthyridine in 1893. However 1, 8-naphthyridine is known as the naphthalene analog of pyridine [2]; these ring systems have given different names, like "benzodiazepines", "pyridinopyridins" etc. depending on the arrangement of the nitrogen atom(s). Six different naphthyridine systems (fig. 1), namely 1, 5-Naphthyridine (1) 1, 6Naphthyridine (2) 1, 7-Naphthyridine (3) 1, 8-Naphthyridine (4) 2,6-Naphthyridine (5) and 2, 7-Naphthyridine (6) are existing at the present time and amongst them 1, 8-Naphthyridine is the novel class of heterocycle [3-8].<smiles>c1ccc2ncccc2c1</smiles><smiles>c1cnc2cccnc2c1</smiles><smiles>c1cnc2cnccc2c1</smiles>

1,5-naphthyridine (1) 1,6-naphthyridine (2) 1,7-naphthyridine (3)<smiles>c1cnc2cccnc2c1</smiles><smiles>c1cc2cnccc2cn1</smiles><smiles>c1cc2cnccc2cn1</smiles>

1,8-naphthyridine (4) 2,6-naphthyridine (5) 2,7-naphthyridine (6)

Fig. 1: Naphthyridines
The naphthyridine ring systems are generally prepared from aminopyridines by using various types of cyclization reactions, very similar to those processes employed in quinoline chemistry. In a few cases, they are prepared by the degeneration of a polynuclear compound or by ring resizing of properly established phthalimides (Sliraup, Doebner-Miller, Doebner, Knorr) [9]. Consequently, a huge quantity of 1, 8-naphthyridine have been synthesized and few of them have reached the clinical stages. These derivatives carry versatile biological activities such as anticancer, cytotoxic, antiinflammatory, antimicrobial, analgesic, antidepressant, antiepileptic, antihypertensive, etc. Many 1, 8-naphthyridine analogs are found to exhibits significant biological activities and have been established as valuable agents in drug research.

\section{1, 8-Naphthyridine (NPTR)}

Amongst the six isomeric pyridopyridines, the derivative having 1, 8naphthyridine (NPTR) ring gained the importance in the last $25 \mathrm{y}$. This group of derivatives has drawn interests mainly owing to the NPTR ring system which is abundant in lots of active derivatives including inherent substances and possesses different biological behavior. The quantity of publications and patents related to the chemical and biological activities of 1, 8-naphthyridines derivatives which were issued and published during this era is more than the number of research on other pyridopyridines in the previous more than $90 \mathrm{y}$. In the few years, more than 900 publications have been published on the relevant topic, amongst which about 200 were patents [10]. A large number of these topics are focused on specific prospects of biological activities and assays. Clinically, the derivatives are more acceptable because of its potent efficacy and minimal side effect. So, by looking at its clinical output and safety margin, 1, 8-naphthyridine nucleus is becoming the prime choice for the researchers for further investigations $[11,12]$. Patent of some 1, 8-naphthyridine derivatives are summarized in the table. Currently, 1, 8-naphthyridine represents an extensively used scaffold with a number of attractive uses in the different pharmacological areas. Thus, a variety of pharmacological activities have been described and reported until now $[13,14]$. Some 
of the modern drugs of naphthyridine moieties (fig. 2) include nalidixic acid (7), tosufloxacin (8), trovafloxacin mesylate (9), enoxacin (10), alatrofloxacin mesylate (11), gemifloxacin (12), and voreloxin (13) which already exist in the market.

Table 1: Patents of 1, 8-napthyridine derivatives

\begin{tabular}{|c|c|c|c|c|}
\hline $\begin{array}{l}\text { S. } \\
\text { No. }\end{array}$ & $\begin{array}{l}\text { Publication } \\
\text { number }\end{array}$ & Publication date & Title of publication & Inventors \\
\hline 1 & US 6,331,548 & Dec. 18,2001 & $\begin{array}{l}\text { 1-Cycloalkyl-1,8-naphthyridin-4-one Derivative as type iv } \\
\text { Phosphodiesterase inhibitor }\end{array}$ & $\begin{array}{l}\text { Shimamoto et al. } \\
\text { [132]. }\end{array}$ \\
\hline 2 & US $6,340,690$ & Jan. 22, 2002 & Antiviral methods using $[1,8]$ naphthyridine derivatives & Bachand et al. [133]. \\
\hline 3 & US $6,451,811$ & Sep. 17, 2002 & $\begin{array}{l}\text { 4-0xo-1,4 dihydro[1,8]naphthyridine } 3 \text {-carboxamides as antiviral } \\
\text { agents }\end{array}$ & $\begin{array}{l}\text { Vaillancourt et } \\
\text { al.[134]. }\end{array}$ \\
\hline 4 & WO 03/027112 & Apr. 3,2003 & 1, 8-Naphthyridine derivatives as antidiabetics & Yamin et al. [135]. \\
\hline 5 & US $6,605,614$ & Aug. 12, 2003 & {$[1,8]$ naphthyridine derivatives having antiviral activity } & Bachand et al. [136]. \\
\hline 6 & $\begin{array}{l}\text { US, } \\
20040014751 \mathrm{~A} 1\end{array}$ & Sep. 26, 2001 & $\begin{array}{l}1,8-N a p h \text { thyridine derivatives and their use to treat diabetes and } \\
\text { related disorders }\end{array}$ & Yamin et al. [137]. \\
\hline 7 & US 7,067,528 B2 & Jun. 27, 2006 & 1, 2-Dihydro-2-oxo-1, s-naphthyridine derivative & Muraoka et al. [138]. \\
\hline 8 & US 7,109,196 B2 & Sep. 19, 2006 & $\begin{array}{l}\text { 1,8-Naphthyridine derivatives and their use to treat diabetes and } \\
\text { related disorders }\end{array}$ & Yamin et al. [139]. \\
\hline 9 & US 7,163,948 B2 & Jan. 16, 2007 & Heterocyclic substituted 1,4-dihydri-4ox9-1,s-naphthyridine analogs & Whitten et a1. [140]. \\
\hline 10 & $\begin{array}{l}\text { US, } \\
20100056563 \mathrm{~A} 1\end{array}$ & Mar. 4, 2010 & Novel 1,8-naphthyridine compounds & $\begin{array}{l}\text { Deodialsingh et al. } \\
\text { [141]. }\end{array}$ \\
\hline 11 & EP1695974B1 & Mar, 17, 2010 & 1,8-Naphthyridines as CRF antagonists & Fabio et al. [142]. \\
\hline 12 & US 7,790,716 B2 & Sep. 7, 2010 & Fab I inhibitors & Miller et al. [143]. \\
\hline 13 & W02005091857A3 & Oct 5,2006 & $\begin{array}{l}\text { 1,6-Naphthyridine and 1,8-naphthyridine derivatives and their use to } \\
\text { treat diabetes and related disorders }\end{array}$ & $\begin{array}{l}\text { Rainer Heurich } \\
\text { [144]. }\end{array}$ \\
\hline 14 & US, 8124773B2 & Feb. 28, 2012 & 1,8-Naphthyridine compounds for the treatment of cancer & Adelman at al. [145]. \\
\hline 15 & $\begin{array}{l}\text { US } \\
2012 / 0316166 \mathrm{~A} 1\end{array}$ & Dec. 13,2012 & Hetarylaminonaphthyridines & Jonczyk et al.[146]. \\
\hline 16 & US $8,470,847$ B2 & July. 25, 2013 & $\begin{array}{l}\text { Derivatives of 7-alkynyl-1,8-naphthyridones, } \\
\text { preparation method thereof and 2011'use of same in therapeutics }\end{array}$ & Alam et al. [147]. \\
\hline 17 & US 8,765,954B2 & Jul. 1, 2014 & 1,8-Naphthyridine compounds for the treatment of cancer & Adelman et al. [148]. \\
\hline 18 & US, 8,912,216 & Dec. 16,2014 & Hetaryl-[1,8]naphthyridine derivatives & Jonczyk et al. [149]. \\
\hline 19 & US, 8,952,164B2 & Feb. 10, 2015 & $\begin{array}{l}\text { R-7-(3-aminomethy-4-methoxyimino-3-methyl-pyrrolidin-1-yl)-1- } \\
\text { cyclopropyl-6--fluoro-4-oxo-1,4-dihydo-[1,8]naphthyridine-3- } \\
\text { carboxylic acid and l-aspartic acid salt, process for the preparation } \\
\text { thereof and pharmaceutical composition comprising the same for } \\
\text { antimicrobial }\end{array}$ & Choi, et al. [150] \\
\hline 20 & US 20150250775 & Sep. 10, 2015 & $\begin{array}{l}\text { Methods of using }(+)-1,4 \text {-dihydro-7-[(3s,4s)-3-methoxy-4- } \\
\text { (methylamino)-1-pyrrolidinyl]-4-ox-o-1-(2-thiazolyl)-1,8- } \\
\text { naphthyridine-3-carboxylic acid for treatment of antecedent } \\
\text { hematologic disorders }\end{array}$ & $\begin{array}{l}\text { Glenn Michelson } \\
\text { [151]. }\end{array}$ \\
\hline
\end{tabular}<smiles>CCc1cn(CC)c2nc(C)ccc2c1=O</smiles>

Nalidixic acid (7)<smiles>Cc1cn(-c2ccc(F)cc2F)c2nc(N3CCC(N)C3)c(F)cc2c1=O</smiles>

Tosufloxacin (8)

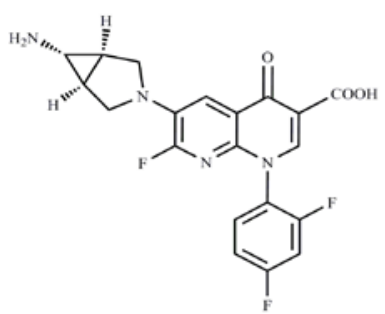

Trovafloxacin mesylate (9)<smiles>CCn1cc(C)c(=O)c2cc(F)c(N3CCNCC3)nc21</smiles>

Gemifloxacin (12)

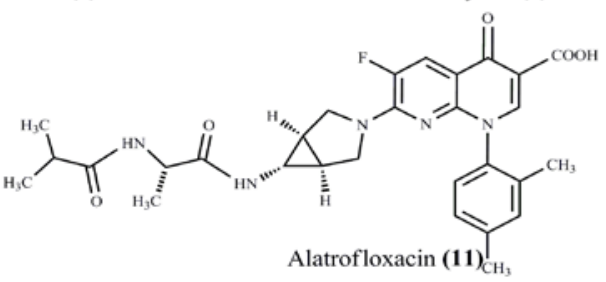<smiles>CCc1cn(-c2nccs2)c2nc(N3C[C@H](C)[C@@H](C)C3)ccc2c1=O</smiles>

Voreloxin (13)

Fig. 2: Marketed antibiotics having a 1,8-naphthyridine nucleus 
Nalidixic acid (7) is useful in the management of various urinary tract infections (UTIs) where the gram-negative bacteria are responsible for the disease $[15,16]$. Tosufloxacin, a fluoroquinolone (8) has potent broad-spectrum activity and its greater activity is found against clinically important gram-positive organisms comparable to that of other fluoroquinolones such as ciprofloxacin and ofloxacin [17]. Trovafloxacin (9) is an important drug active against Gram-negative species. It exhibits 8 to 16 time greater activity than that of either ofloxacin or ciprofloxacin [18]. Enoxacin, a quinolone (10) has a broad-spectrum antibacterial activity and is used mainly in the treatment of UTIs and STDs [19]. Alatrofloxacin, a fluoroquinolones antibacterial compound (11) has outstanding activity against bacteria [20]. Gemifloxacin mesylate (12), a synthetic well known broad-spectrum antibacterial agent is generally used orally [21]. Voreloxin (13) a novel NPTR derivative, which is structurally associated with the quinolone antibiotics, a chemical group not known previously for anticancer properties [22-27].

Synthetic analogs of 1, 8-naphthyridine, exhibiting various pharmacological activities

\section{Antimicrobial activity}

Antibiotics are the most imperative agents in healing bacterial infections and have an important benefit for the health-related quality of our lives since their introduction in the medical field. On the other hand, over the past few decades, these health profits are below threat as several regularly used antibiotics become less effective against some bacteria and certain illnesses. The thoroughly increasing, the occurrence of multi-drug resistant against antibiotics, microbial infections in the last few decades have developed into a severe health care problem. To investigate novel antibacterial drug will thus persist as an essential and demanding task for the researcher. Development and advancement in new antimicrobial drugs are yet in the demand of the day due to microbial resistance, whereby 1, 8-Naphthyridines are imperative components in novel antibacterial drug discovery [28-30]. Gohil et al. [31] synthesize new chromeno $[4,3-f][1,8]$ naphthyridines analogs $(14 a-d)$ by a multicomponent reaction and evaluate for their antimicrobial activity. The compounds with 4-fluorophenyl (14a),3-trifluoromethyl (14b), 6-Amino-8-(4-fluorophenyl) (14c) and 6-Amino-12-methoxy-8-(3(trifluoro-methyl)phenyl)-(14d) shows excellent antimicrobial activity against both type of bacterial strains with MIC value 50 $\mathrm{mg} / \mathrm{ml}$, and also the compounds (14a) and (14c) exhibit excellent antifungal activity with MIC value $250 \mathrm{mg} / \mathrm{ml}$. The activities might be attributed due to the substitution of electron withdrawing group (F, CF3). Furthermore, derivatives having methyl group exhibit a reasonable activity, In addition, triazole substituted derivatives exhibit the excellent antifungal activity with MIC value $250 \mu \mathrm{g} / \mathrm{ml}$ ).
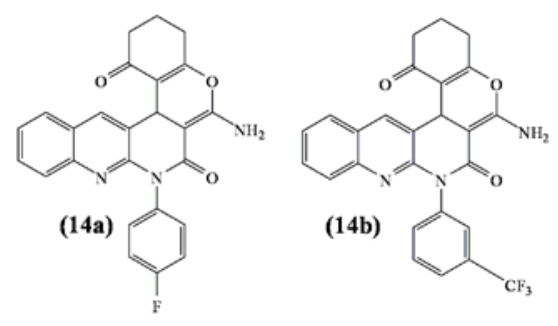

Structure-activity studies indicate that 1, 4-dihydro-4-oxo-3-pyridinecarboxylic acid moiety is necessary for antimicrobial activity. The pyridone scaffold has to be annotated by an aryl ring. Isosteric replacements of nitrogen atom for carbon atoms at positions 8 are reliable with the protection of antimicrobial activity. The addition of substitutes at position 2 significantly decline activity; positions $5,6,7$ and 8 of the annulled rings could be substituted with excellent activity. For example, piperazinyl and 3-aminopyrrolidinyl substitutions at position 7 show better activity with compounds of the quinolone class against the gram-negative strain of $P$. aeruginosa. Substitution of fluorine atom also significantly enhances antibacterial activity [32]. Substitution of alkyl at the 1-position is necessary for antibacterial

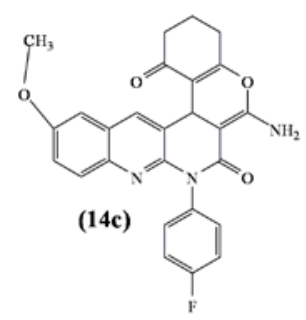

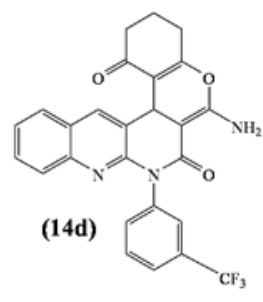

activity, small alkyl derivatives normally having better efficacy. Addition of aryl at the 1-position is also steady with antimicrobial activity, with a 2, 4-difluorophenyl group provides the best efficacy. Ring condensations at the 1,8 positions also produce active compounds. Arayne et al. [33] synthesize different enoxacin analogs via nucleophilic substitution at the C3 position of the drug by primary aromatic amines. The free carboxylic acid group is used as a target for the synthesis of amide derivatives, and the result of functional group substitution on various biological activities of the parent compounds was studied. The derivative (15-19) exhibits antimicrobial activity against both the strains of bacteria through better activity, is found in the case of gram-negative strains.

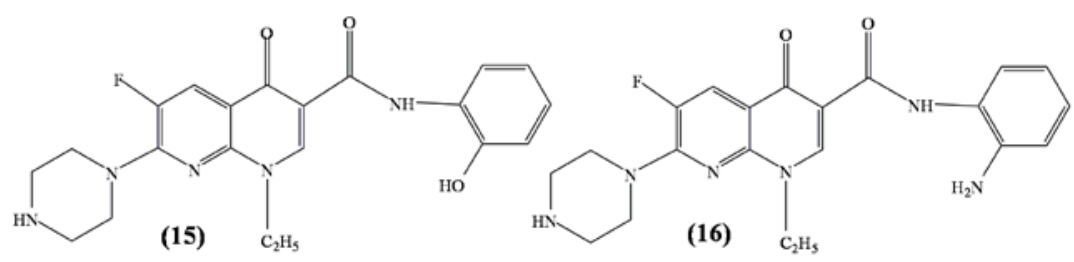

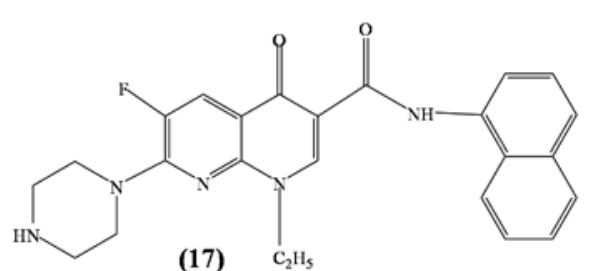<smiles>CCCCCn1cc(C(=O)Nc2ccccc2)c(=O)c2cc(F)c(N3CCNCC3)nc21</smiles>

(17)

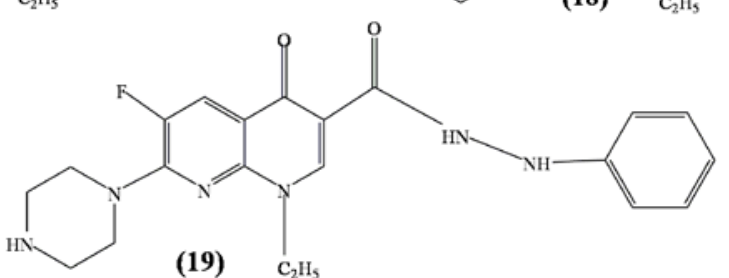


Lv et al. [34] synthesize new naphthyridone analogous having mono/difluoro-methyloxime pyrrolidine ring system with remarkable improvement in lipophilicity (20 and 21$)$. In in vivo experiments, a compound with 7-(3-aminomethyl group) (21) shows more activity than that of its parent drug against the test bacterial strains, and particularly its activity is 5.2-6.1 times more active than ciprofloxacin and gemifloxacin against gram-negative bacteria P. aeruginosa with $\mathrm{ED}_{50}$ value $21.27 \mathrm{mg} / \mathrm{kg}$.

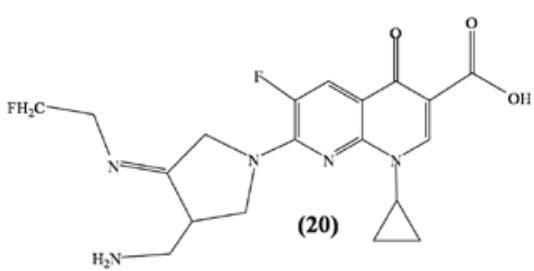

Feng et al. [35] synthesize new gemifloxacin analogs having substituted benzyloxime group with significant enhancement in the lipophilic property. Most of the compounds show significant potency against tested strains including methicillin-resistant $S$. epidermidis

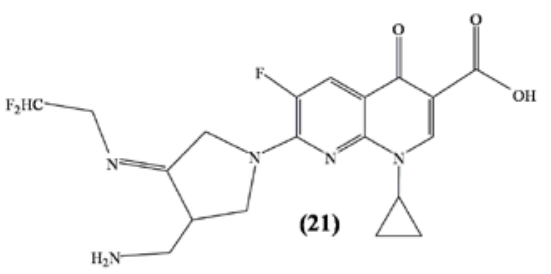

and S. aureus (MIC: $<0.008-8 \mu \mathrm{g} / \mathrm{ml}$ ). Compound (22) a 2, 5 Dimethoxyl derivative show 2-128 and8-2048 times more activity than that of gemifloxacin and levofloxacin, respectively with MIC $<0.008-4 \mu \mathrm{g} / \mathrm{ml}$.

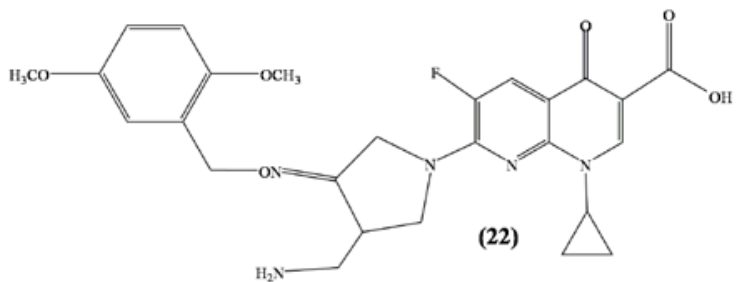

Aggarwal et al. [36] synthesize new nalidixic acid based 1, 3, 4-thia/oxa diazoles, their bis mercapto, sulfones, thioethers, and Mannich bases derivatives (23-25). These compounds show a moderate to excellent antibacterial activity against the tested bacterial strain. The compounds having thiadiazole moiety show better antimicrobial activity as compared to compounds having oxadiazoles moiety. Compound (23) a thiadiazole derivative show good activity against $K$. pneumoniae, $B$. subtilis, and P. aeruginosa with a MIC value from 6.25-125 $\mu \mathrm{g} / \mathrm{ml}$.

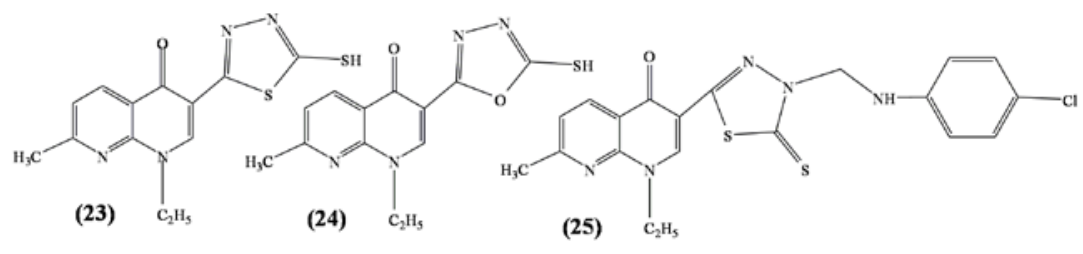

Fadla et al. [37] synthesize a new series of Schiff bases and evaluate their antimycobacterial activity. The lead Schiff base N'-(1-benzyl-2oxoindolin-3-ylidene) substituted 1, 8-naphthyridine-3-carboxylic acid (26) exhibits remarkable inhibitory activity against four Mycobacterium strains: M. cheleneo, M. intercellulari, M. xenopi, and M. smegmatis. The para substitution, of a benzyl moiety with electron withdrawing groups, in $\mathrm{N}$-benzylisatins is seven-times more active as shown by N'-(1-(4-chlorobenzyl)-2-oxoindolin-3ylidene) substituted 1, 8-naphthyridine-3-carboxylic acid (27) (Z)-1ethyl-N'-(1-(4-fluorobenzyl)-2-oxoindolin-3-ylidene) substituted 1, 8-naphthyridine-3-carboxylic acid (28a) and (Z)-1-ethyl-7-methylN'-(1-(4-nitrobenzyl)-2-oxoindolin-3-ylidene) substituted 1, 8naphthyridine-3-carboxylic acid (28b) with fluoro, $p$-chloro and nitro substituent respectively.<smiles>Cc1ccc2c(c1)N(C)C=C(C(=O)NC[C@@H]1C3CCCCC3N(CC3=CCCCC3)C1O)C2</smiles><smiles>CC1CCC2CC(C(=O)NNC3C(=O)N(C)C4CCCCC34)CN(C)C2C1</smiles>

(27)

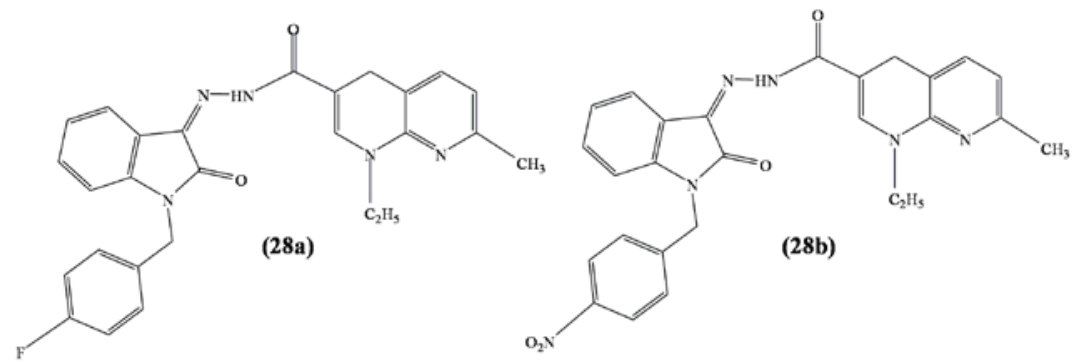


Jalal et al. [38] synthesize various modified 4-morpholinomethyl-1.8-naphthyridine derivatives and evaluate their antitubercular activities against M. tuberculosis strain H37Rv in vitro.
The compound 1,8-naphthyridine analog (29) with a 6-amino-2(4'-methoxybenzylamine-4-morpholinomethyl-7-morpholinosubstituent shows good activity with a MIC of $0.25 \mu \mathrm{g} / \mathrm{ml}$ and offers a promising new lead for further development.

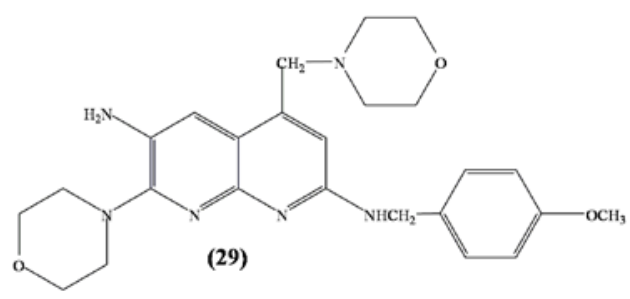

The field of coordination chemistry of metal complexes is growing rapidly because of its versatile and broad utilization in medical and biomedical fields [39]. The biological effectiveness of metal ions draws great interest to many researchers for the development and application of inorganic compounds with possible biologically active ligands. Quinolones are having 4-oxo3-carboxylic-1, 4-dihydroquinoline frame is a bioligand, having bactericidal properties, good oral absorption, outstanding bioavailability, and high penetration power into tissues. Nalidixic acid (Nal) is the first member of quinolones [40]. It effectively inhibits the growth of gram-negative bacteria and is used for the treatment of different infectious diseases like UTIs, typhoid fever, bone-joint infections, respiratory infections, soft tissue infections, community-acquired pneumonia, and sexually transmitted diseases.

Zakya et al. [41] synthesize various complexes of nalidixic acid with addition of Zn (II), Fe (III), Ca (II), Mg (II), and VO (II) ions and evaluate their antibacterial potentialities. The antibacterial activities of the synthesized compounds were tested against gram-negative and grampositive bacteria, i.e. E. coli, S. albus as well as fungi, such as A. flavus and $A$. niger. The ligand coordinates in a bidentate manner via one carboxylate oxygen atom and the oxygen atom of the pyridine carbonyl group. The Zn (II) complex (30) exhibits the best activity amongst all. The biological activities, find out in the following order: $\mathrm{Zn}$ (II)-Ndx>VO (II)-Ndx $>\mathrm{Fe}$ (III)-Ndx> $\mathrm{Mg}$ (II)-Ndx>Ca (II)-Ndx.
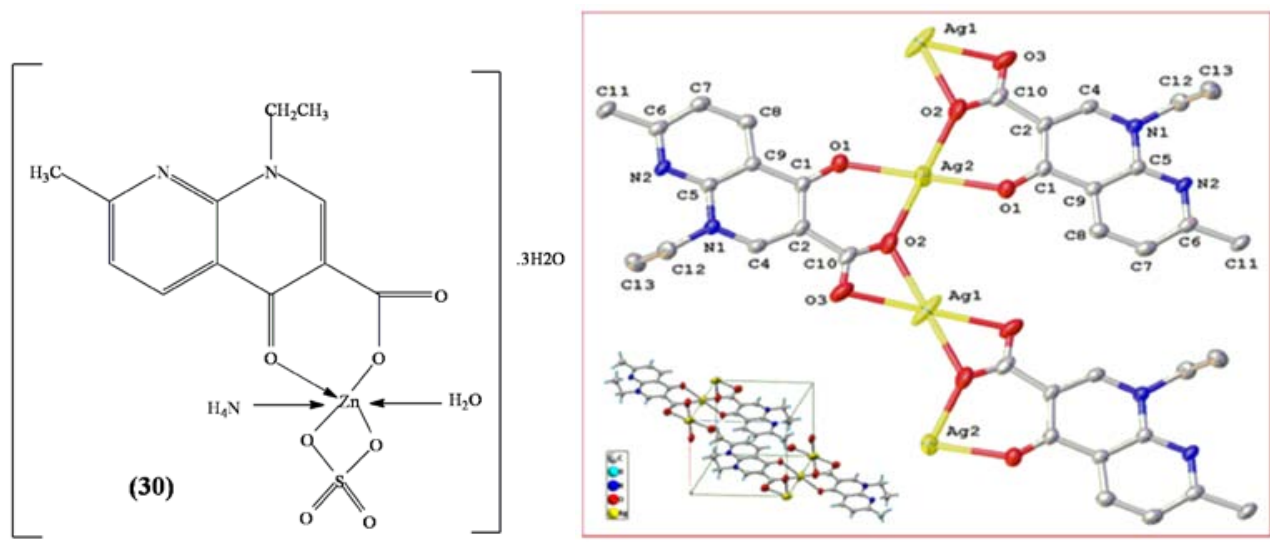

Fig. 3: Crystal structure of [Ag(Nal)2] Complex [Sourse: Debnath et al. Rus J Gen Chem 2013;83:2488-2501]

Debnath et al. [42] synthesize a new binuclear square planar complex of nalidixic acid with silver (Ag) metal ion (fig. 3) having the molecular formula as $\left[\mathrm{Ag}(\mathrm{Nal})_{2}\right]$. The ligand is bonded to $\mathrm{Ag}(\mathrm{I})$ ion via the carboxylate oxygen and pyridone. The synthesized metal ion complex exhibits excellent antifungal activity as compared to that of nalidixic acid when tested against four fungal strains, S. rolfsii, $R$. solani P. aphanidermatum, and $R$. bataticola. Saleh et al. [43] report an easy and regioselective synthesis of- 2 chloro-3- formyl-1, 8-naphthyridine, through Vilsmeier-Haack cyclization of $N$-(pyridine-2-yl) acetamide. The 1,2,4-triazole, 1,3,4-thiadiazol and 1,3,4-oxadiazole derivative, 5(2-chloro-1, 8-naphthyridine-3-yl)-4H-1,2,4-triazole-3-thiol (31), 5-(2-chloro-1, 8-naphthyridine-3-yl)-1,3,4-thiadiazol-2-amine (32) and 5-(2-chloro-1, 8-naphthyridine-3-yl)-1,3,4-oxadiazole-2(3H) -thione 33) demonstrate good antibacterial activities against $S$. epidermidis and S. aureus.

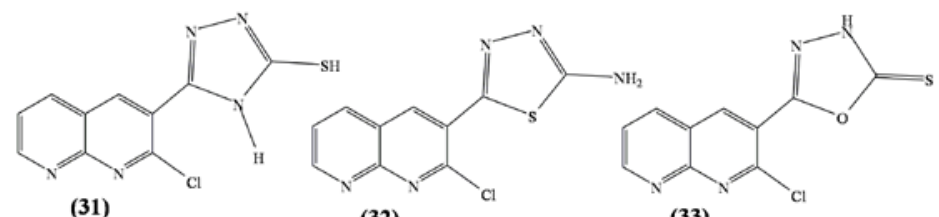

(31)

(32)

(33)

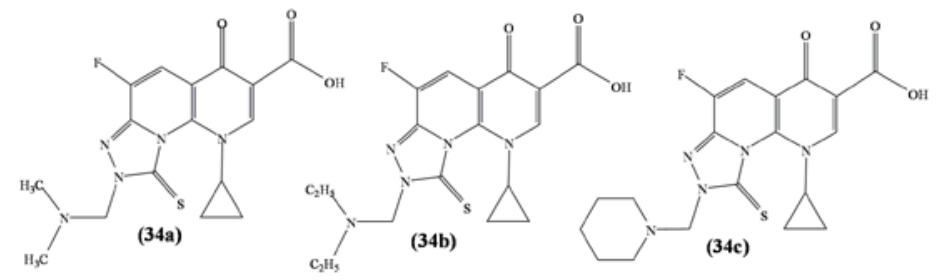


Gao et al. [44] synthesize new tricyclic fluoroquinolones, (34a-h) containing an efficient Mannich-base moiety at the C-8 position. The compounds (34e-g) with a piperazine side chain show similar antibacterial activity than that of ciprofloxacin. In addition, the compounds also show broad-spectrum antibacterial activity, including both gram-positive and gram-negative microorganism.
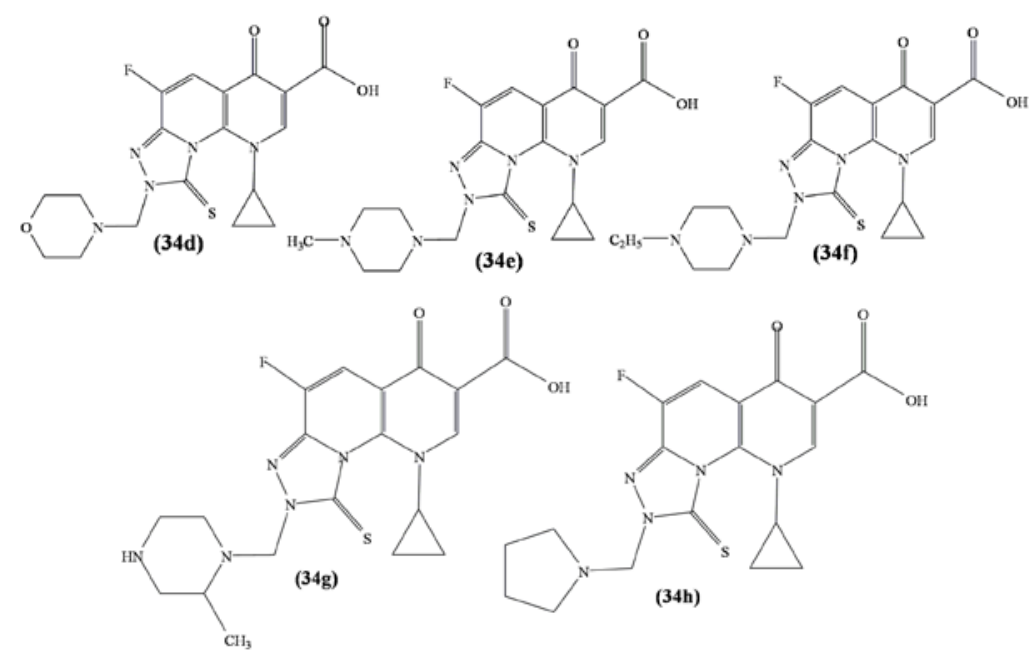

Acosta et al. [45] synthesize various 1, 8-naphthyridine derivatives by microwave-assisted synthesis with heterocyclic $o$-aminonitriles and cyclic ketenes catalyzed by $\mathrm{ZnCl}_{2}$ and produce a series of pyrazolo $[3,4-b][1,8]$ naphthyridine-5-amines. The derivatives with a 4 -p-tolyl substituent at naphthyridine skeleton $(35 \mathrm{a}, 35 \mathrm{~b}$ and 35c) are most active against $C$. albicans, which appear to be linked with their corresponding hydrophobicity. Amongst these compounds, 3-methyl-1-phenyl-4-p-tolyl substituted, 1, 8naphthyridine-5-amine (35a), having a cyclohexyl fused ring, exhibits excellent activity.<smiles>CC1CCC(C2C(C3CCCCC3)C3C(N)C4CCCCC4CC3C3C(C)NC(C)C32)CC1</smiles>

Donalisio et al. [46] study the effects of 1, 8-naphthyridine derivatives (36) that effectively inhibit the transcription, regulated by the long control region of human papillomavirus (HPV) genome. They investigate with a sequence of analogs to get more effective derivatives like quinoline and thiazol substituted piperazine at 7<smiles>CC1CCC(C2C3C(NC4CCCC4C3C)NC3C2C(C)CN3C2CCCCC2)CC1</smiles>

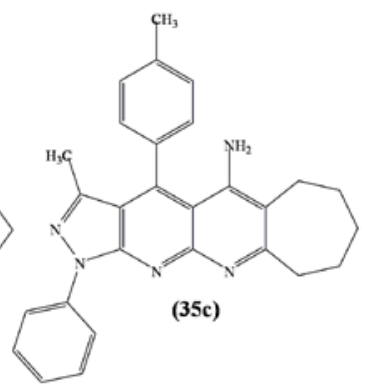

positions (37) and (38). These compounds have the ability to downregulate E6 and E7 transcripts in human papillomavirus (HPV-16) positive cervical cancer CaSki cells. The 1,8-naphthyridines appear as a satisfactory beginning mark for the development of novel compounds effective for the management of HPV-induced cervical cancer.

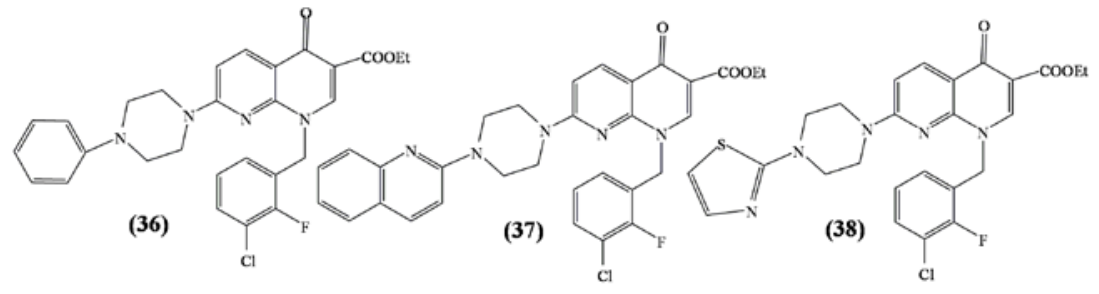

Sakram et al. [47] Synthesise substituted 1,8-naphthyridines based on 2-aminonicotinaldehyde and evaluate their antimicrobial property against various bacterial strains like $S$. aureus, $B$. subtilis, $E$. coli, and K. pneumonia and anti-fungal activity toward A. flavus and $F$. oxysporum. Compounds 2-Butyl-3-iodo-1,8-naphthyridine (39a), 2Hexyl-3-iodo-1,8-naphthyridine (39b) and 3-Iodo-2-phenyl-1,8naphthyridine $(39 \mathrm{c})$ show maximal zone of inhibition against the test microorganisms as compared to that of standards drug.<smiles>CC1CC2CCCCC2CC1I</smiles>

(39a)<smiles>CC1NC2CCCCC2CC1I</smiles>

(39b)<smiles>IC1CC2CCCCC2CC1C1CCCCC1</smiles> 
Valadbeigi and Ghodsi [48] synthesize a series of N-[2-(8-methoxy-2Hchromen-2-one)ethyl] piperazinyl quinolones having a carbonyl linked functional groups on the ethyl spacer of coumarin and piperazine rings and observe their antimicrobial activities against both gram-positive and gram-negative strain, B. subtilis PTCC 1207, E. coli PTCC 1047 and a fungus strain, C. kefyr ATCC 38296 respectively. Amongst these, the compound with 7 substituted piperazine and chromen moiety (40) shows the most potent in vitro antimicrobial activity.

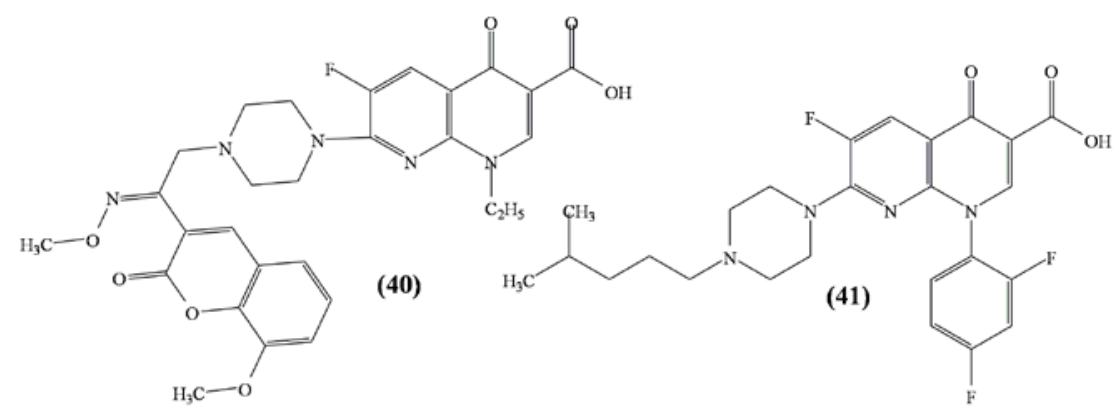

Gençer et al. [49] synthesize a new series of 7-substituted fluoroquinolones and evaluate their antimicrobial activity against both gram-positive and gram-negative bacteria strain. Compound bearing a 4-dimethylaminopropylpiperazin-1-yl substituent (41) show good antibacterial activity and DNA gyrase inhibition similar to that of ciprofloxacin, moxifloxacin, and trovafloxacin with the MIC90 value $1.95 \mu \mathrm{g} / \mathrm{ml}$ against $S$. aureus, and E. coli.

\section{Antihistaminic activity}

Sherlock et al. [50] describe a new class of antiallergic compounds, the substituted l, 8-naphthyridine-2 $(1 H)$-ones which associate in the prohibition of the discharge of the leukotrienes and sulfidopeptide. Structure-activity relationship studies of the lead scaffold in this series, l-phenyl-3-n-butyl 4-hydroxynaphthyridine-2 (lH)-one identify three derivatives of importance, 1, 8-naphthyridine substituted with l-phenyl (42a) 1, 8-naphthyridine substituted with 1-(3'-chlorophenyl) (42b) and 1, 8-naphthyridine substituted with 1-(3'-methoxyphenyl) (42c). Compound (42a) is chosen as the lead for preclinical development as an antiallergic compound.

Nishikawa et al. [51] synthesize oxo-pyridine carboxamide derivatives and evaluate their antiallergic activities. The 1, 8 naphthyridine-3-carboxamides (43a and 43b) is found potent antiallergic agent in the rat passive cutaneous anaphylaxis (PCA) test and also exhibit excellent inhibitory activity in vitro than that of caffeic acid against 5-Lipoxygenase.<smiles>COC1CCCC(N2C(O)C(C)C(C)C3CCCNC32)C1</smiles>

(43a)

\section{As Antihypertensive agents}

Different cardiovascular diseases like ischemia, hypertension, and arrhythmias are treated by $\beta$-adrenoreceptor antagonists. Though $\beta$ adrenergic inhibitors are incredibly uniform in their chemical structures, only a few $\beta$-blockers related to 1, 8-naphthyridine derivatives have been described till date [52]. Badawneh et al. [53] synthesize various substituted 1, 8-naphthyridine analogs, and study their antihypertensive activity. The 4-(N-methylencyclo-alkylamino)-1, 8-naphthyridine derivatives with various substitutions in positions 2 and 7 show satisfactory levels of potency (pIC50>5where as the compound (44) $\mathrm{N}$ ethoxycarbonylpiperazin-1-yl derivative) reached a really interesting value ( $\mathrm{pIC}_{50}$ value of 6.92 ). The $\beta$-antagonist activity of $(\mathrm{R}, \mathrm{S})$-(E)-oxime ethers of 2, 3-dihydro-1, 8-naphthyridine and of 2, 3-dihydrothiopyrano [2, 3-b] pyridine (45) has $\beta_{3}$-blocking properties, It is notable that these compounds, have bulky substituents at position 7 and with these 4-tbutylphenoxy or 4-chloro-phenoxy groups show an impressive downturn in both $\beta_{1}$-and $\beta_{2}$-antagonist activities.

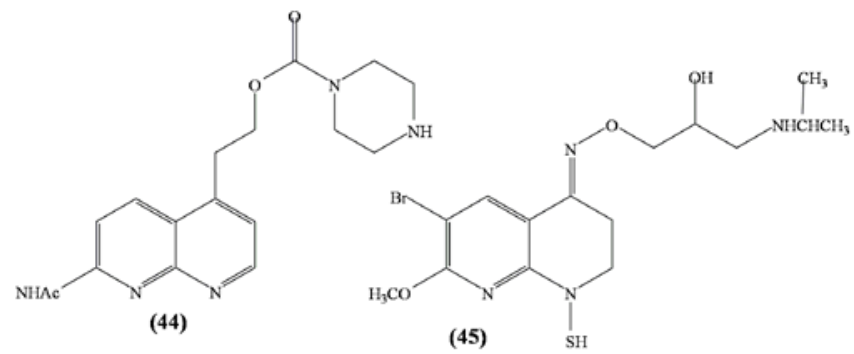


Jalal et al. [54] synthesize new derivatives of 1, 8-naphthyridine from 7-amino-2-hydroxy-4-morpholinomethyl-1,8naphthyridine. The analogs of either 7-hydroxy-2- $N$ - ethoxycarbonylpiperazine or a 7-hydroxy-2-piperazine substituent (46a and 46b) show a higher affinity towards $\beta_{1}$ receptors.<smiles>CC1CCC2C(CN3CCOCC3)CC(N3CCNCC3)NC2N1</smiles>

\section{Anticancer and antitumor activity}

Cancer or malignancy is a most important burden of disease of worldwide, it is a group of diseases characterized by uncontrolled growth of cells and has potential to occupy or spread to other parts of the body [55-57]. A number of anticancer agents are at present in clinical use. To find new anticancer agents, the discovery of a number of 1, 8-naphthyridine (NPTR) derivatives is the new addition. Recently, NPTR and quinolines well-known heterocyclic compounds are being introduced in cancer chemotherapy and in this circumstances, 'Voreloxin' is already in clinical use [58]. The entire NPTR derivatives exhibit limited cytotoxic activity against murine P388 leukemia cells. Eweas et al. [59] synthesize new 2, 7-Dimethyl-1, 8-naphthyridine derivatives substituted with Schiff's bases, Mannich bases N- $\beta$-glycosides, pyrazolone, and S-alkylated. Furan derivative (47) 1, 8naphthyridine hydrazide exhibit cytotoxic activity against the HepG2 cell line ( $\mathrm{IC}_{50}$ equals $\left.3.2 \mu \mathrm{g} / \mathrm{ml}\right)$. The results are comparable with 5-Fluorouracil and doxorubicin as standard drugs ( $\mathrm{IC}_{50} 5$ and $3.56 \mu \mathrm{g} / \mathrm{ml}$ ) respectively.

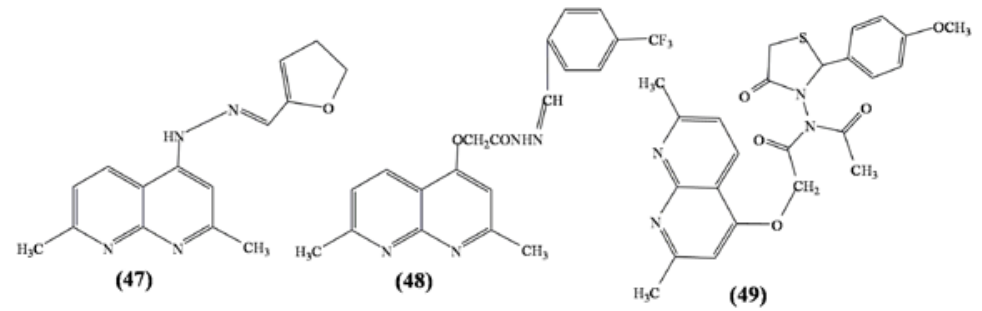

Ahmed et al. [60, 61] synthesize novel Schiffs bases, thiazolidine, and pyrazolidine by the use of versatile synthon 4-hydroxy-2, 7dimethyl-1, 8-naphthyridine and evaluate for their cytotoxic activity. Compounds (48) (2-(2,7-Dimethyl-1, 8-naphthyridine-4-yloxy)-N(4-methoxybenzylidene) acetohydrazide) and (49) (N-Acetyl-2-(2,7dimethyl-1, 8-naphthyridine-4-yloxy)-N-(2-(4-methoxyphenyl)-4oxothiazolidin-3-yl) Acetamide) show the maximum cytotoxic activity against the HepG2 cell line with $\mathrm{IC}_{50}$ value 0.047 and 0.041 $\mu \mathrm{M}$, respectively. The versatile synthon 2-(2, 7-dimethyl-1, 8naphthyridine-4-yloxy) acetohydrazide. (50) (1, 2, 4-triazole incorporated 1, 8-naphthyridine) shows the maximum cytotoxic activity against the HepG2 cell line with the $\mathrm{IC}_{50}$ value of $0.048 \mu \mathrm{M}$.
Elansary et al. [62] report synthesis of various 2, 4, 5, 7tetrasubstituted pyrido [2, 3-d] pyrimidines and their allied isosteres substituted 1, 8-naphthyridines and study their anticancer activity. Compound, 7-(4-chlorophenyl)-5-(3-nitrophenyl)-2-phenyl1, 8-naphthyridine-4-amine (51) shows potent to moderate growth inhibitory activity. Fu et al. [63] develop a proficient synthesis of new functioned 1, 8-naphthyridine and chromeno [2, 3-b] quinoline derivatives (52) via cascade reaction of 2-chloroquinoline-3carbaldehyde and enaminones or cyclic 1, 3-dicarbonyl compounds. All the derivatives are evaluated for their cytotoxic activity in vitro against various cancer cells and a number of derivatives are established to have higher activities.

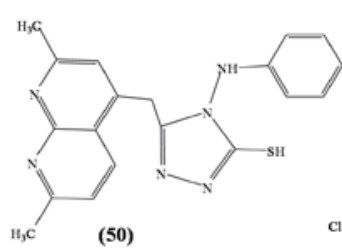

(50)<smiles>CCCCCC(C)C1CC(C)CC2C(C)CCC(C3CCCCC3)C12</smiles><smiles>CC1CC(C)C2CC3CCC(C)C(C)CC3C(C)C2C1</smiles>

evaluated for their antitumor activity against 60 different cell lines. Compounds, (53a) NPTR fused with cyclopentane and (53b) NPTR fused with cyclohexane show notable anticancer activity against tumor cell lines, with significant $\mathrm{GI}_{50}$ values $0.62-2.18 \mu \mathrm{M} / \mathrm{ml}$. amines by microwave assisted organic reaction involving cyclic ketones and heterocyclic $o$-aminonitriles and the reaction is catalyzed by $\mathrm{ZnCl}_{2}$ leading to the new procedure. These compounds are

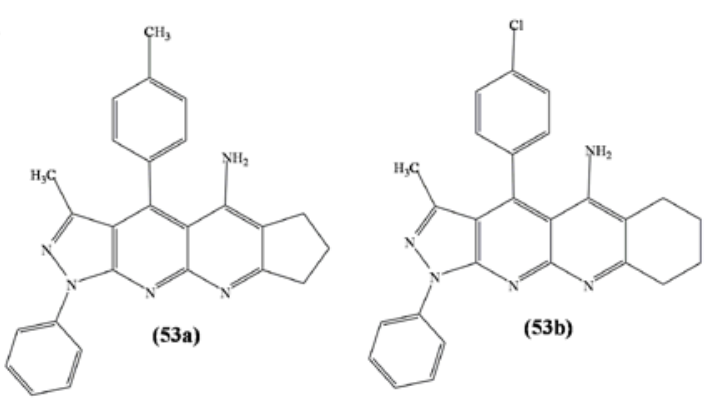


Graf et al. [64] investigate the reaction of cyclometallated rhodium and iridium complexes with 2-methyl-1,8-naphthyridine and 4-chloro-2methyl-1,8-naphthyridine and evaluate their cytotoxic activity towards the HT-29 and MCF-7 cancer cell lines. Rhodium complexes (54a and c), and iridium complexes (54b and d) show significant cytotoxic activity against both the cancer cell lines in the subordinate micromolar range. Amongst these complexes, maximum activity is calculated for (54d) with IC 50 values of $1.67 \mu \mathrm{M}$ for MCF-7 and $2.83 \mu \mathrm{M}$ for HT-29. In addition, it is found that the complexes (54b) and (54d) attribute a somewhat more anticancer activity towards both the cell lines in comparison to the rhodium analogous (54a) and (54c), respectively. Jia et al. [65] develop a series of naphthyridinone derivatives analogous to Voreloxin (13) and evaluate their in vitro anticancer activity against HL60 cell line. Compound (E)-7-(3(aminomethyl)-4-(benzyloxyimino)-3-methylpyrrolidine-1-yl)-4-oxo1-(thiazol-2-yl)-1,4-dihydro-1,8-naphthyridine-3-carboxylic acid (55) shows wide range of activity with $\mathrm{IC}_{50}$ value ranging from $0.5-6.25$ $\mathrm{mmol} / \mathrm{l}$ against all the tested cancer cell lines.

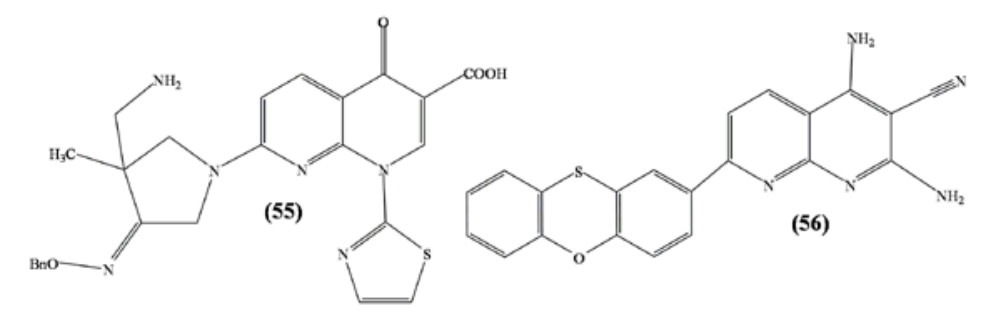

Behalo et al. [66] synthesize a series of pyrido [2,3-d]pyrimidine and 1,8-naphthyridine derivatives and evaluate their anticancer activity against MCF-7, and PC-3 cancer cell lines using MTT assay. The compound, 1,8-naphthridincarbonitrile (56) is found to be a most effective anticancer agent against PC-3 cell line with $\mathrm{IC}_{50}$ values ranging from 9.47, 10.34, and $8.13 \mu \mathrm{g} / \mathrm{ml}$ respectively. The compound also shows strong anticancer activity against MCF-7 cell line. Tang et al. [67] synthesized a sequence of pyrrolo [2,3-b] pyridine compounds containing the 1,8-naphthyridine-2-one group and studied their anticancer activity against HT-29, H460, A549, and U87MG cell line and six tyrosine kinases (c-Met, VEGFR-2, EGFR, Flt3 , PDGFR- $\beta$, and c-Kit inhibition activities. Maximum compounds show good to outstanding activity and pyrrolo pyridine substituted 1,8-naphthyridine-3-carboxamide compound (57) shows Kinase inhibition activity for Flt-3/c-Met with an IC50 value of 1.16/1.92 nM.

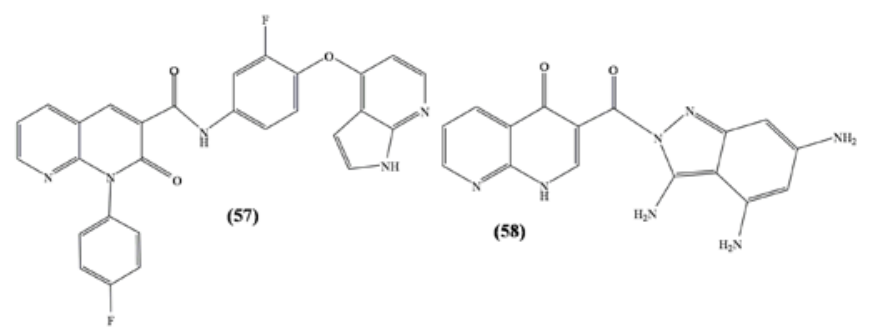

Melha [68] synthesizes a series of pyrazolo pyridine substituted 1, 8naphthyridine derivatives and evaluate their cytotoxic activity against Ehrlich ascites carcinoma (EAC). Compound (58) pyrazolo pyridine substituted 1, 8-naphthyridine shows the best cytotoxicity and antioxidant activity against EAC.

\section{5-HT ${ }_{3}$ receptor antagonists}

Amongst the serotonin family, $5-\mathrm{HT}_{3}$ receptor draws much more interest due to the therapeutic use of $5-\mathrm{HT}_{3}$ receptor antagonists in the management vomiting, nausea induced by cancer chemotherapy, postoperative nausea vomiting (PONV) and other clinical uses. In addition, several preclinical studies recommend that $5-\mathrm{HT}_{3}$ receptor antagonist may use the management of different CNS diseases $[69,70]$.
Gautam et al. [71] studies various piperazine substituted 8naphthyridine-3-carboxylic acid derivatives for their $5-\mathrm{HT}_{3}$ receptor inhibition and anxiolytic-like activity in rodent behavioral models. Compound (2-(4-phenylpiperazine-1-yl)-1, 8-naphthyridine 3carboxylic acid) (59) has good $\log \mathrm{P}$ (3.35) and pA2 value (7.6) greater than that of standard drug, ondansetron (pA2-6.6).

Compound (60) (2-methoxy-1, 8-naphthyridine-3-yl) (2-methoxy phenylpiperazine-1-yl) methanone and (61) is selected as the lead compounds which show a pA2 value of 7.67. The naphthyridine-3carboxamide (2-Ethoxy-1, 8-naphthyridine-3-yl) [4-(3-methoxyphenyl) piperazin-1-yl] methanone) (62) exhibit outstanding $5-\mathrm{HT}_{3}$ receptor antagonistic activity with pA2 values of 7.5. [72-75].<smiles>COC1CC(C(=O)C2CCN(C3CCCCC3C)CC2)CC2CCCNC2C1</smiles>

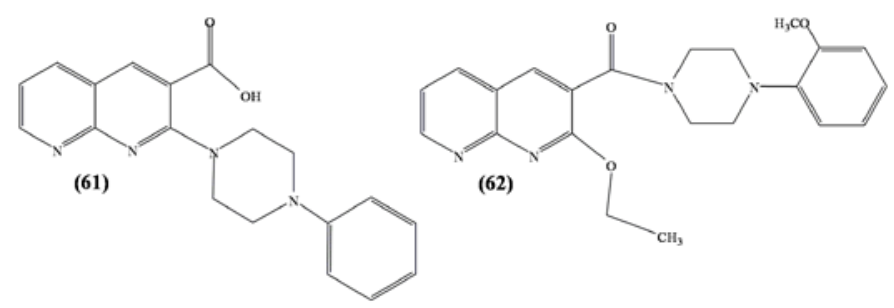




\section{CB1 receptor inverse agonists}

The cannabinoid-1 receptor (CB1) is present mostly in the CNS which is stimulated by the endocannabinoids (ECs) which are endogenous lipid-based retrograde neurotransmitters. A contrary agonist/antagonist action of the CB-1 receptor have the capacity to overcome food intake in both humans and other animals. Inhibition of CB1 receptor can be used effectively in the treatment of obesity $[76,77]$. Duggan et al. [78] synthesize and study SAR of the CB1 receptor adverse agonists derived from dihydro-pyrano [2, 3-b] pyridine and tetrahydro-1, 8-naphthyridine scaffolds. Rat food intake and pharmacokinetic study of compound (63) shows that tetrahydro-1, 8-naphthyridine bicyclic core structures, are orally useful in regulation of food intake and body weight in a rodent model.

\section{CB2 receptor agonists with anticancer and immunomodulatory activity}

Manera et al. [79] design and synthesize 1, 8-naphthyridine-4 (1H)on-3-carboxamide and quinoline-4 (1H)-on-3-carboxamide derivatives. Compound (64) (p-fluorobenzyl and carboxycycloheptyl amide) substituents present at 1 and 3 positions of the 1,8 naphthyridine-4-one nucleus, show greater affinity toward CB2 with a $K 1$ of $1.0 \mathrm{nM}$. The 1-morpholino substituted compounds (65-68) show good CB2 affinity and CB2 versus CB1 selectivity.

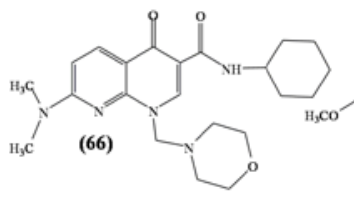

Furthermore, they find that their efficiency is restricted due to the presence of the substituents at C- 6 of the naphthyridine ring and 4hydroxy-2-oxo-1, 2-dihydro-1, 8-naphthyridine derivatives characterize by a 4 methyl cyclohexyl amido substituted in position 3 of the heterocyclic nucleus with higher CB2 receptor efficacy and preference [80]. The $p$-fluorobenzyl quinoline-2-one derivative (69) and the morpholino ethyl derivative (70) show the excellent affinity
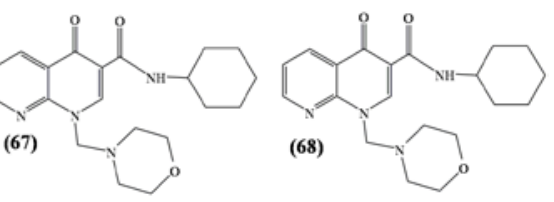

and selectivity and act as a full agonist and a partial agonist at the CB2 receptor and induce a concentration-dependent decline of cell capability on lymph node carcinoma of the prostate (LNCaP), cell line expressing the CB2 receptor [81]. Regarding CB2R affinity, the compounds ( 69 and 70 ) prove as compounds of interest to have a maximum affinity, with Ki values of $0.7 \mu \mathrm{M}$ and $1.5 \mu \mathrm{M}$ and $4.5 \mu \mathrm{M}$ respectively [82].

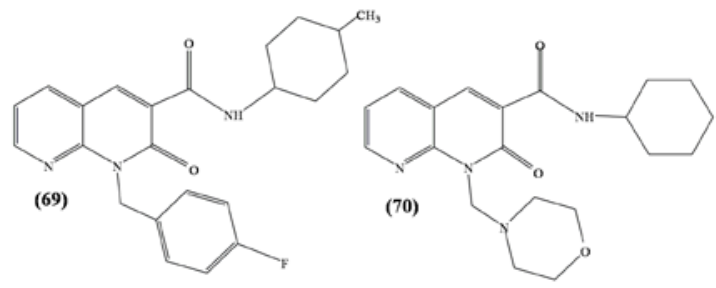

Saccomanni et al. [83] study the synthesis of novel aryl iodonium salts used as precursors for single-stage nucleophilic [18] F radio fluorination. The radiolabeled compound [[18] F] 1, 8naphthyridine-3-carboxamide (71) is effectively synthesized for in vivo administration, and its pre-bio-distribution is assessed with
micro-PET/CT. The results indicate that [[18] F] CB1 is a potential candidate marker for distribution of CB2 receptor. Manera et al. [84] synthesize derivatives of quinoline and NPTR and evaluate affinity and selectivity for the CB2 receptor. Compounds (72 and 73) show the excellent affinity and selectivity profile for the CB2 receptor.

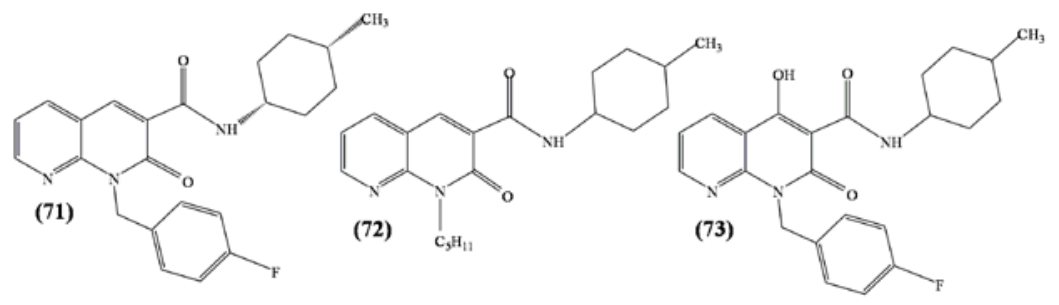

Malfitano et al. [85] study 1, 8-naphthyridine derivatives effects and the defensive role of the $\mathrm{CB}$ receptor in various neurological disorders. In this case study, the immunomodulatory and antiinflammatory property of the designed compounds along with their possible intestinal absorption and blood-brain barrier (BBB) permeability have been found out. The test compounds, (74-76) show inhibition of the peripheral blood cells proliferation of the tested cell. The anti-proliferative effects of compound 1-benzyl, $\mathrm{N}$ - cyclohexyl substituted l, 8-naphthyridine-3-carboxamide (75) and 1(4-fluorobenzyl), $\mathrm{N}$-(4-methylcyclohexyl) substituted 1,8naphthyridine-3-carboxamide (76) are moderately intervened by the CB2 receptor. These derivatives block the cell cycle and CB91 decline $\mathrm{T}$ cell activation. Compounds downregulate the expression of phosphorylated proteins like NF- $\mathrm{KB}$, extracellular receptor kinase, Akt and COX-2 enzyme, CB91 inhibits the function of the CB2 receptor and its activity is regulated by $\mathrm{CB} 2$ receptor<smiles>Cc1ccc2c(n1)N(CCN1CCOCC1)CC(C(=O)C1CCCC1)C2=O</smiles> 
He also studies the potential immunomodulatory activity of 1 , 8naphthyridine and quinoline derivatives in activated lymphocytes isolated from multiple sclerosis patients. Compounds are found to block cell explosion by a mechanism that partially attributed to the CB2 receptor, down-regulated TNF- $\alpha$ production and does not provoke cell decrease. They also down-regulate ERK, Akt, and NF-kB phosphorylation. NPTR and quinoline derivatives inhibit cell activation markers. In multiple sclerosis patient isolated lymphocytes more effective than in that cell isolated from healthy control. In fact, 1, 8-naphthyridine-2-one derivative reduces the levels of the Cox-2 enzyme in lymphocytes. [86]. He also develops cycloheptyl substituted derivative VL15 (78) as a selective CB2 receptor agent with high selectivity and affinity at the $\mathrm{CB} 2$ receptor and havening excellent protective role of this receptor in various neurological diseases with an autoimmune constituent like multiple sclerosis with immunomodulatory activity [87].

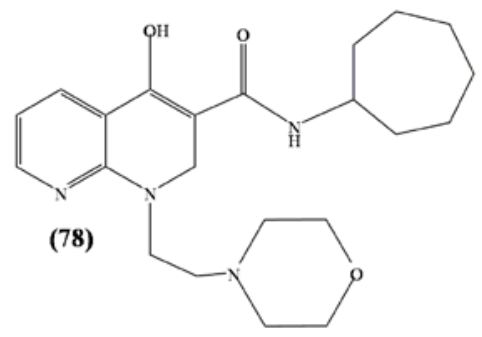

\section{Anti-HIV activity}

Human immunodeficiency virus type 1 (HIV-1) integrase is a viral enzyme that catalyzes the incorporation of the viral DNA into the host cell DNA, an essential step for virus replication. This process is completed via successive strand transfer, involving elimination of the terminal dinucleotide from each 30-terminal of the target viral DNA followed by successive joining of the 30-terminal of the target viral DNA of the host DNA. This virus-encoded enzyme is required for the completion of the viral replication cycle and thus illustrates a very attractive target for designing antiretroviral drugs [88, 89] Nagasawa et al. [90] develop an HIV-1 integrase inhibitor (79a and b) which shows much-improved human microsome stability up to 75-97\%. The halogenated phenyl derivatives of 1,8-naphthyridine3-carboxylic acid (79a) and (79b) may be selected for further development.

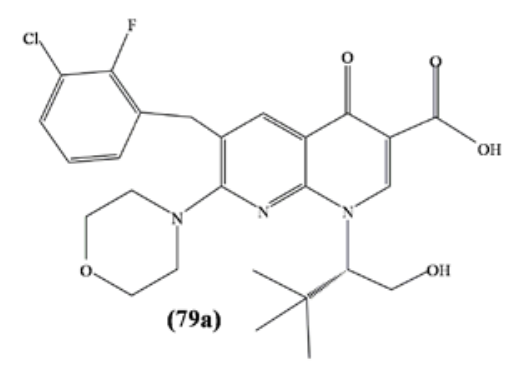

Zhao et al. [91, 92] synthesize bicyclic inhibitors having a hydroxyl group at position 1 and 4 in 1, 8-naphthyridine-3-carboxamide scaffolds and evaluate their HIV1 integrase inhibitory activity. Amongst these amides, N-(2,4-difluorophenyl)-1-hydroxyl substituted 1, 8-naphthyridine-3-carboxamide (80a) and $\mathrm{N}$-(2,4-difluorophenyl)1,4-dihydroxyl substituted 1, 8-naphthyridine-3-carboxamide (80b) show antiviral activity in nanomolar range potencies against HIV-1 integrase. Most of the derivatives show selectivity index more than 20,000 , and several compounds have better antiviral potencies than raltegravir against a group of integrase mutants consist of $\mathrm{N} 155 \mathrm{H}$,<smiles>COC1N=C2[C@@H](CC1[IH]CC1C(C)CC(I)CC1F)C(O)C(C(=O)O)CN2C(CO)C(C)(C)C</smiles>

Y143R, G118R, and the double mutants G140S/Q148H and E138K/Q148K. He also studies substituted 1, 8-naphthyridine-3carboxamides integrase inhibitors (81a and b) to search the agents that have better potential against recombinant integrase in biochemical assays. Amongst the new inhibitors, compound 2-(3-(2,4difluorobenzylcarbamoyl)-1-hydroxy-2-oxo-1,2-dihydro-1,8naphthyridine-4-ylamino) ethyl acetate (81a) shows a profile against the panel while substituted 4-amino 1, 8-naphthyridine-3carboxamide (81b) exhibits the best overall absolute performance approximately five to 10 fold enhancement.<smiles>O=C(Nc1ccc(I)cc1I)c1cc2cccnc2n(O)c1=O</smiles><smiles>O=C(Nc1ccc(F)cc1F)C1C(=O)N(O)C2=CCCCC2=C1O</smiles><smiles>CC(C)c1c(C(O)C=Cc2ccc(F)cc2F)c(=O)n(O)c2ccccc12</smiles>

Massari et al. [93] describe that 1,8-naphthyridine (82), has a promising anti-HIV activity, which has the capability to block the<smiles>Nc1c(C(=O)NCc2ccc(F)cc2F)c(=O)n(O)c2ccccc12</smiles>

HIV-1 Tat-mediated transcription. This lead to the discovery of naphthyridine derivative NM13 as the most promising compound, 
gained from MT-4 cells. The introduction of an amino group at the C6 position of 1, 8-naphthyridine nucleus characterizes many of the potent 6-desfluoroquinolones. Benzothiazolyl derivative of 1,8naphthyridine-3-carboxylic acid (83) show better anti-HIV activity, whereas 6-amino derivative of 1,8-naphthyridine-3-carboxylic acid (84) bearing the pyridinyl piperazine as a C7 substituent, show reasonable activity along with little cytotoxic activity along with positive SI values [94].<smiles>Cn1cc(C(=O)O)c(=O)c2cc(C(=O)O)c(N3CCN(c4ccccn4)CC3)cc21</smiles>

\section{Anti-Inflammatory activity}

Non-steroidal anti-inflammatory drugs (NSAIDs) are much more useful drugs in the management of moderately and chronic inflammation, fever, and pain. However, unvarying clinical usage of well-known NSAIDs is associated with a wide range of unwanted side effects including bleeding, gastrointestinal lesions, and nephrotoxicity. Thus, the discoveries of the novel and therapeutically safe and anti-inflammatory drugs represent an additional challenge to the researcher $[95,96]$. Due to the development of resistance against anti-inflammatory drugs, there is an increasing demand for the discovery of novel, potent and less toxic anti-inflammatory drugs $[97,98]$. Madaan et al. [99] synthesize a series of 1, 8-naphthyridine-3-carboxamide derivatives (85a-c) and evaluate their anti-cancer and anti-inflammatory activity. The derivatives of 1, 8-naphthyridine-3-carboxamide substituted with 7chloro-N-(3-(cyclopentylamino) (85a), 7-chloro-N-(2-hydroxy-3oxo-1-phenyl-3-(phenylamino) (85b) and 7-chloro-6-fluoro- $\mathrm{N}-(2$ hydroxy-3-oxo-1-phenyl-3-(phenylamino) (85c) show considerable activities. Amongst these, compound (85c) shows effective antiinflammatory activity on inflammatory markers in dendritic cell model at 0.2 and $2 \mu \mathrm{M}$. It also very much declines the secretion of IL6 , TNF- $\alpha$, and IL-1- $\beta$ by murine splenocytes and Tamm-Horsfall Protein 1 (THP-1) cells against lipopolysaccharides induced levels.

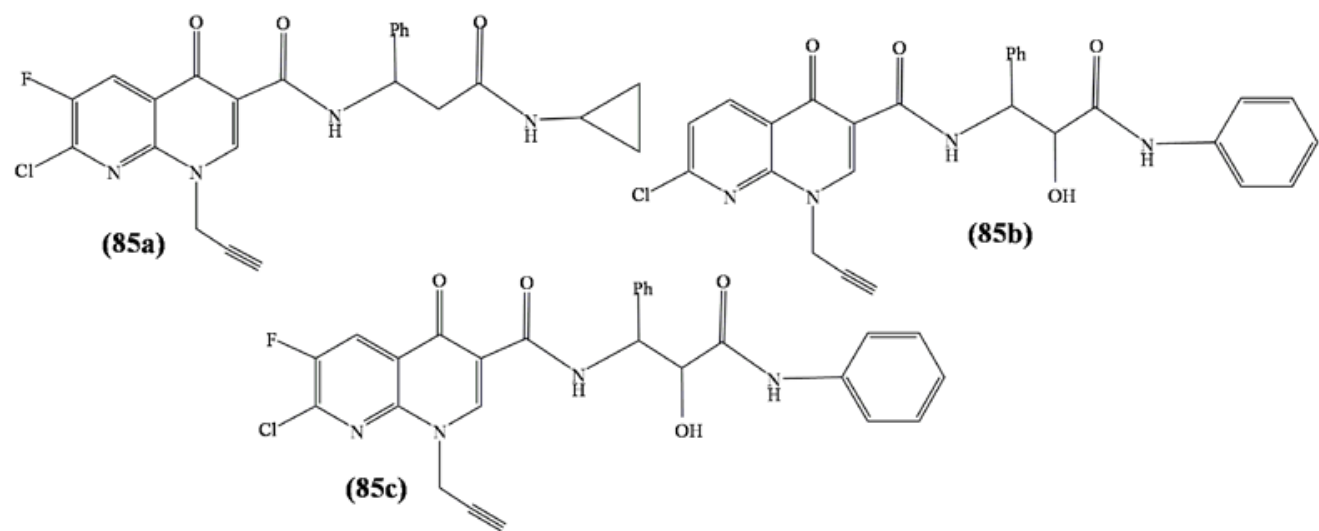

Braccio et al. [100] synthesize 5-(alkylamino)-9-isopropyl [1, 2, 4] triazole derivatives of 1,8 naphthyridines containing a CONHR moiety at 6 positions and evaluate their anti-inflammatory behavioral patterns. The compound exhibits good anti-inflammatory activity in rats. The most active compound (86) shows significant anti-inflammatory activity with percentage oedema inhibition values of $80 \%(\mathrm{P}<0.01)$ and $72 \%(\mathrm{P}<0.01)$ at the doses of $100 \mathrm{mg} / \mathrm{kg} 50$ $\mathrm{mg} / \mathrm{kg}$, respectively [100].<smiles>CC(C)C1NNC2C1C1CCCCC1C(C(C)C)C2C(C)C</smiles>

\section{As new ligand of $\mathrm{A}_{2 \mathrm{~A}}$ adenosine receptor}

Adenosine is perhaps more important neuromodulator in the CNS and peripheral nervous systems, its formation generally rises under metabolically favorable conditions. This nucleoside controls its effects throughout the activation of four subtype adenosine receptors located on the cell surface and recognized as the $A_{1}, A_{2 A}, A_{2 B}$, and $A_{3}$. In the peripheral system, the $A_{2 A} A R$ is located in different tissues, and then $\mathrm{A}_{2 \mathrm{~A}} \mathrm{AR}$ agonists can be used to decrease platelet aggregation in thrombosis, ischemia for determining the strength of antiinflammatory and immunosuppressive properties. In view of all the above, much effort and contribution of $\mathrm{A}_{2 \mathrm{~A}} \mathrm{AR}$ have been focused in the 
last few years toward the discovery and development of selective $\mathrm{A}_{2 \mathrm{~A}} \mathrm{AR}$ ligands [101]. Manera et al. [102] synthesize 1, 8-naphthyridine derivatives containing different substituent (87a-d) at position 3,4 , and 7 of the heterocyclic nucleus. The synthesized compounds do not have any affinity towards $A_{1} A R$, while several of them have the capacity to gain an interesting activity and selectivity for the $A_{2 A} A R$. All the synthesized compounds demonstrate a significant efficacy for $\mathrm{A}_{2 \mathrm{~A}} \mathrm{AR}$, with Ki values ranges from 30.0-67.0 $\mu \mathrm{M}$.<smiles></smiles>

(87a)<smiles>O=C(NCc1ccccc1)c1c[nH]c2nc(Cl)ccc2c1=O</smiles>

(87c)<smiles>CN(C)c1ccc2c(=O)c(C(=O)NCc3ccccc3)c[nH]c2c1</smiles>

\section{$A_{1}$ adenosine receptor antagonist}

Ferrarini et al. [103] synthesize derivatives of NPTR containing a phenyl group at position 2 and different substituents at 4 and 7 positions. The substitution at position 7 significantly alter the

affinity and the most attractive substitutes at this place seem to be by electronegative groups; as in the 7-chloro-2-phenyl-1, 8naphthyridine-4-ol (88) where an excellent selectivity linked with a good $\mathrm{A}_{1}$ affinity (Ki) $0.15 \mu \mathrm{M}$ ) was found.<smiles>OC1CC(C2CCCCC2)NC2CC(Cl)CCC12</smiles>

\section{Selective AChE inhibitor}

Alzheimer's disease (AD) is a chronic neurodegenerative, irreversible disorder that is clinically characterized by a successive loss of various cognitive and functional abilities [104]. It is the most general form of dementia in Western countries, which has caused intense economic and social impact as the aging population elevates. Though a lot of factors have been concerned in the AD, its etiology and pathogenesis remain indefinite. The 'cholinergic hypothesis' describes the most useful approaches associated with the design of new drugs for the management of AD. This approach is based on the development of drugs with an acetylcholinesterase inhibition profile in order to restore the deficiency of cerebral acetylcholine [105]. Klenc et al. [106] invent the first radiotracer targeting the GPR91, which is a cell surface-bound receptor that controls the cellular effect to hypoxia and hyperglycemia; they design and prepare a series of NPTR derivatives (89a and b) with excellent affinity to GPR91. Pharmacological assays confirm the lead compounds for 99mTc and 18F GPR91 radiotracers within the series.

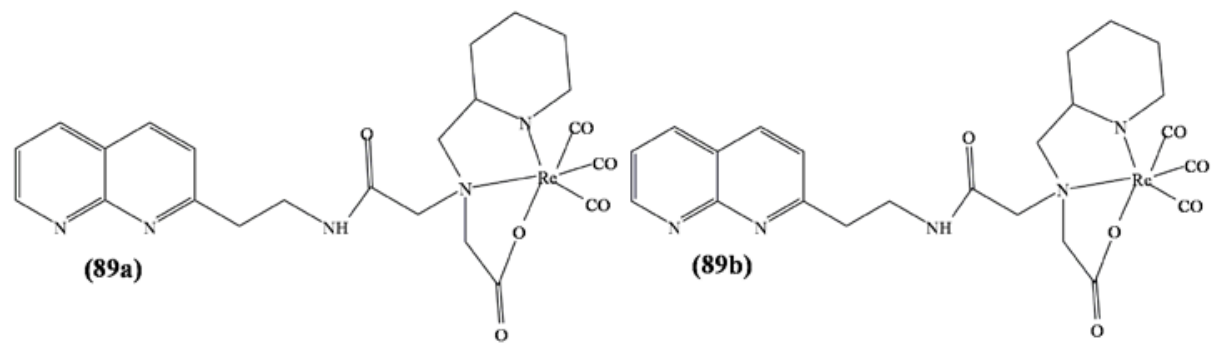

\section{Other activities}

\section{Potent gastric antisecretory properties}

Gastric endoscopic submucosal dissection (ESD) can cause artificial gastric ulcers, and there is no compromise regarding the possible perioperative management in conditions of anticipation of intra-or postoperative bleeding and support of healing. The gastric antisecretory effects of various naphthyridine derivatives have attempted to enter as a therapeutic drug for the healing of peptic ulcer [107-109]. Santilli et al. [110] and they describe the syntheses of 2-oxo-1, 8-naphthyridine-3-carboxylic acid derivatives (90a and b) containing efficient gastric antisecretory activity. The ethyl ester 4amino-l-ethyl-1,2-dihydro-2-oxo 1,8-naphthyridine-3-carboxylic acid (90a) and ester of substituted 4-(4-methyl-l-piperazinyl) l, 8naphthyridine-3 carboxylic acid (90b) show good gastric antisecretory property and are chosen for further exhaustive assessment.

\section{Atypical antipsychotic agents}

Sekhar et al. [111] provide a series of 2,5-disubstituted thiazolylphenylethyl-piperazine derivatives of 1, 8-naphthyridine scaffold in search of a novel, atypical antipsychotic drugs. Compound 2-(4-(4(2-amino-5-methylthiazol-4-yl) phenethyl) piperazine-1-yl)-1, 8naphthyridine-3-carbonitrile (91) exhibits good antipsychotic activity amongst the synthesized derivatives with $5-\mathrm{HT}_{2 \mathrm{~A}} / \mathrm{D} 2$ ratio of

1.1286 


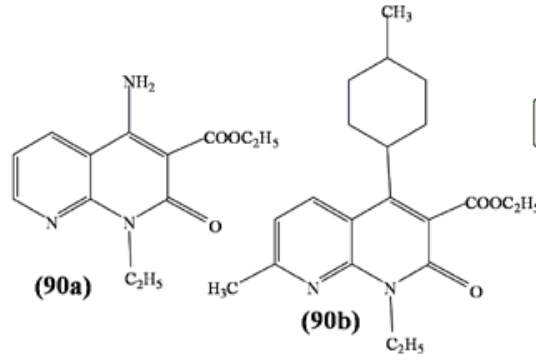

\section{Antiplatelet activity}

Ferrarini et al. [112, 113] synthesize 1, 8-naphthyridine derivatives, containing 2-cycloalkylamino-3-phenyl as substituents at position 6and 7 (92 and93) and 2, 7-di (N-cycloamino)-3-phenyl substituted compound (94) and assess their antiplatelet activity. All the

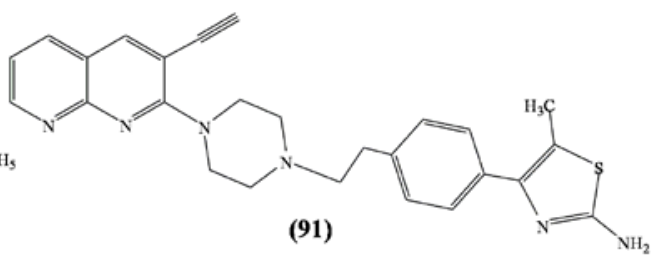

synthesized derivatives demonstrate a significant antiplatelet action in the test with arachidonate and collagen comparable to that of standard drug indomethacin. In the test with ADP, compound (94) exhibits a considerable activity. The presence of morpholinyl or a piperidinyl like a moiety at position 2 and a halogen group like chlorine or a methoxy group at position 7 of the NPTR nuclei appear to favor a good activity.<smiles>COc1cc2nc(N3CCOCC3)c(C3CC=CCC3)cc2cc1[18O]</smiles>

\section{DNA stabilizing agents}

Naik et al. [114] describe the synthesis and molecular docking studies of new benzo $[b][1,8]$ naphthyridines. The docking results reveal that the synthesized compounds favor the binding with ATrich region of ds-DNA. The highest binding energy was found for benzo $[b][1,8]$ naphthyridine-5-thiol $(95)$ and it is-7.16 $(\mathrm{kcal} / \mathrm{mol})$. It offers a promising agent as an enantioselective binder with ds-DNA than the other compounds of benzo $[b][1,8]$ naphthyridines. Photo irradiated at $365 \mathrm{~nm}$, to benzo [1, 8]- naphthyridines find to support the photocleavage of plasmid pUC19 DNA. Dhamodharan et al. [115] observe the synthesis of bispyridinium and bisquinolinium derivatives of NPTR and report their relations between the human telomeric DNA and promoter G-quadruplex building DNAs. The bisquinolinium ligands bind strongly and selectively to quadruplex DNAs at low ligand concentration. The fluorescent intercalator displacement (FID) assay is estimating that naphthyridine bisquinolinium ligands (96a and b) create good binding affinity and also have selectivity for quadruplex DNAs over duplex DNA.

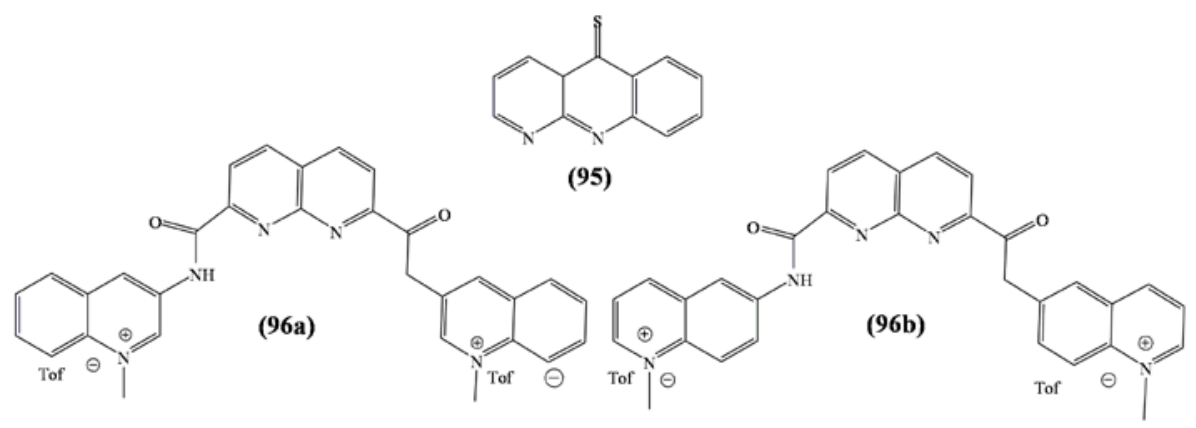

\section{Acyl-CoA: cholesterol acyltransferase inhibitor}

Ban et al. [116] synthesize 4-Aryl-1, 8-naphthyridine-2 (1H)-on3 -yl urea derivatives with hydrophilic groups for the purpose of getting better aqueous solubility and pharmacokinetics property. Compound SMP-797, 1-(4-amino-2, 6-diisopropyl- phenyl)-3-(1-butyl-4-(3-(3-hydroxypropoxy) phenyl)-2-oxo-1, 2dihydro-1, 8-naphthyridine-3-yl) urea (97) having (4aminophenyl) ureido and 3-(hydroxypropoxyphenyl) moieties shows effective Acyl-CoA: cholesterol acyltransferase (ACAT) inhibitory properties with excellent oral efficiency.

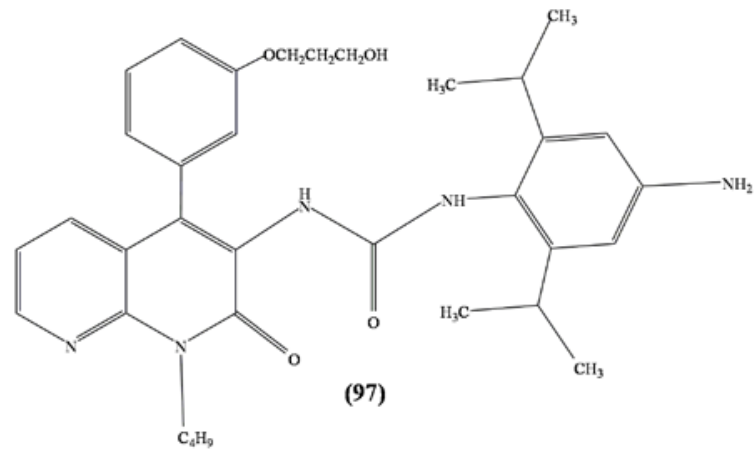




\section{MEK (mitogen-activated protein kinase) inhibitors}

Kanouni et al.[117] synthesize and develop 1, 8-naphthyridine-2,5dione (98a-d) and evaluate MEK kinase inhibitory activity. Most of the compounds show activity against MEK1 kinase. All analogs show activity in sub-micromolar range against MEK through assays in cellular and enzymatic levels.

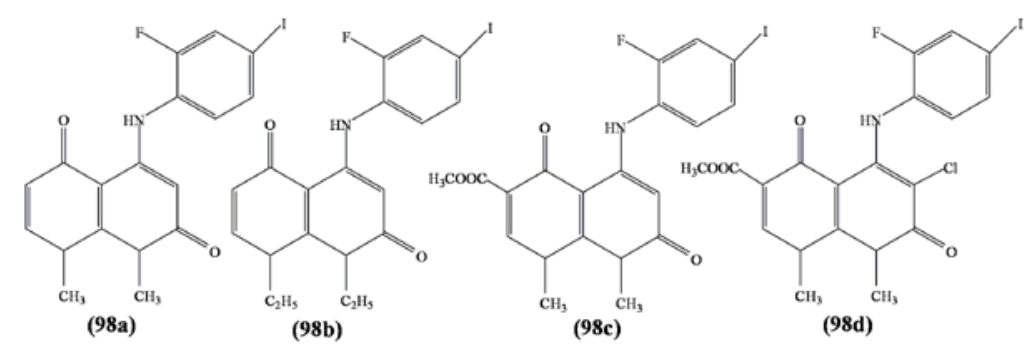

\section{Phosphodiesterase (PDE 4) inhibitors}

Takayama et al. [118] prepare new and phosphodiesterase (PDE4) inhibitor. The compounds show selective inhibitory activities against PDE4 obtained from human peripheral blood cells and are inactively applicable to other PDE types $(1,2,3,5)$. The compound 4, 5, 7-Trimethyl-1-phenyl-1, 8-naphthyridine-2 (1H)-one (99)-YM10335) having 1 , 8-naphthyridine-2 $(1 H)$-one skeleton completely differ structurally from rolipram and is selected as a lead compound. The derivatives also produce good inhibitory activities against TNF$\alpha$ release (in vitro) and carrageenan-induced pleurisy (in vivo) assay.

\section{Inhibitors of $\alpha_{v} \beta_{3}$}

The progress of effective and safe medication for the management of osteoporosis there still remains a growing field of developing research. Osteoporosis occurs due to the difference between the natural processes of bone resorption and bone growth. The first step in bone resorption is the unique function of the osteoclast cells which is regulated by glycoprotein, $\alpha_{v} \beta_{3}$ integrin. An unusual way to interrupt this mechanism is the minimization of osteoclast cells activity by introducing $\alpha_{v} \beta_{3}$ integrin inhibitors [119]. Hartner et al. [120] synthesize 3(S)-(6-Methoxypyridin-3-yl)-3-\{2-oxo-3-[3-[5, 6, 7, 8-tetrahydro-[1, 8]-naphthyridine-2-yl) propyl]-imidazolidin-1$\mathrm{yl}$ \} propionic acid (100) and identify it as an effective and selective $\alpha_{v} \beta_{3}$ receptor antagonist. It has an outstanding in vitro profile with an $\mathrm{IC}_{50}$ value of $0.08 \mu \mathrm{M}$ which is an important unbound part in human plasma and serves as a remarkable pharmacokinetics profile for the dog, rats, and rhesus monkey. Nagarajan et al. [121] describe the synthesis and $\alpha_{\mathrm{v}} \beta_{3}$ inhibitory activity of numerous small molecules like 2-(2-(4-(2-(5, 6, 7, 8-tetrahydro-1, 8-naphthyridine2-yl) ethoxy) phenyl) cyclopropyl) acetic acid (101). Most of the compounds show remarkable selectivity over $\alpha_{v} \beta_{6}$.<smiles>CC1CCC(C(CO)N2CCN(CCCC3CCC4CCCCC4C3)C2=O)CC1</smiles>

\section{Anticonvulsant and CNS activity}

Despite the wide and increasing range of antiepileptic drugs available for treatment, around $30 \%$ of epileptic patients experience faulty seizure control. Again, further $25 \%$ of patients fell serious adverse effects. Thus, there is a need to develop more efficient antiepileptic drugs that would be endowed with an improved safety profile. Recently, a lot of fused pyrimidine compounds are developed as effective drug molecules. Such an important family of the compounds is quinazolinones which are the constituents of about 150 naturally existing alkaloids and drugs. Some NPTR derivatives also show remarkably good anticonvulsant and CNS depressant activity [122]. Stuk et al. [123] study the NPTR derivatives having different moieties (102) for anxiolytic activity which may be due to the partial agonist action of benzodiazepine at the site of the $\mathrm{GABA}_{\mathrm{A}}$ receptor. Lorrio et al. [124] investigate the neuroprotective profile of ethyl 5-amino-2-methyl-6, 7, 8, 9-tetrahydro benzo [b] [1, 8] naphthyridine-3-carboxylic acid ester (103-ITH12246) through in vitro models for Alzheimer's disease. They also find the pharmacological activities of ITH12246 and evaluate its capacity to counter the memory mutilation elicited by scopolamine, a muscarinic antagonist characterized to approve memory loss. They also succeed to moderate the infarct amount in mice suffering from photothrombosis.

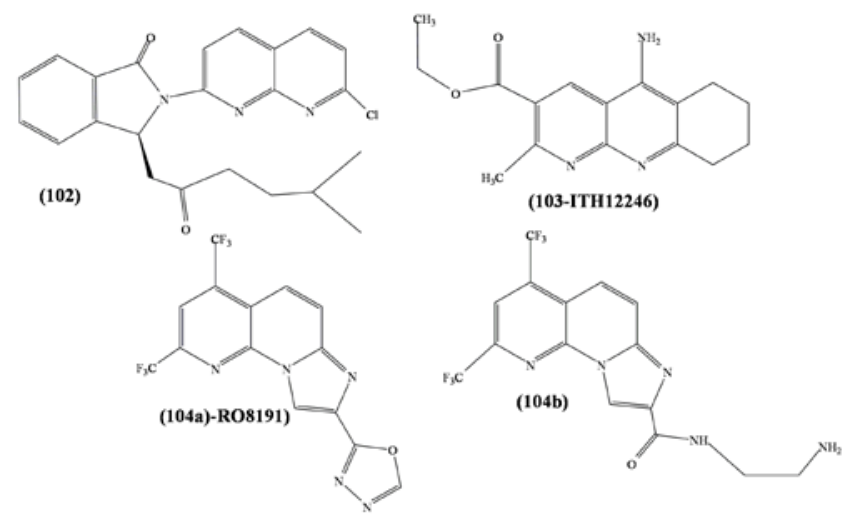


Wang et al. [125] synthesize the derivatives containing an imidazo $[1,2-\alpha][1,8]$ naphthyridine core and a side chain connected with amide bond (104a-R08191 and b) and evaluate the HCV entry inhibitory activity in hepatitis $C$ virus cell culture system. Among these compounds, a few compounds exhibit outstanding anti-HCV activity with $\mathrm{EC}_{50}$ value ranges from 0.017-0.159 $\mu \mathrm{M}$ and low toxicity $\left(\mathrm{CC}_{50}>25 \mu \mathrm{M}\right)$. These novel anti-HCV compounds exhibit antiviral activity by a different mechanism of action as that of R08191 by targeting the viral entrance route.

\section{Antioxidants activity}

The finding of simple organic compounds endowed with good antimicrobial and antioxidant properties is of growing concern in the food industries. Preservation and protection of industrial food containing polyunsaturated fatty acids (eicosapentaenoic (20:5 $\omega-3)$ acid) have become a hot subject and growing interest because of their importance in human nutrition. For example, Omega-3-
Polyunsaturated fatty acids provide a number of health benefits related to cardiovascular disease, immune disorders, inflammation condition, allergic manifestations and the occurrence of diabetes. Several compounds having antioxidant activity have been used to slow down the radicals associated with oxidative reactions. However, some of them are known to produce toxic and carcinogenic side effects in animal models $[126,127]$. The discovery of compounds that can demonstrate both antimicrobial and antioxidant activities having no or zero side effects are most welcome. Nam et al. [128] demonstrate that the C7 unsubstituted tetrahydro-1, 8-naphthyridine-3-ol (105a-d) have greater trapping activity than $\alpha$ tocopherol in inhibiting autoxidations in benzene. The C7-mono and dialkyl analogs exhibit higher antioxidant activity in benzene, as found out by a recently developed peroxyl radical clock. The closest $\alpha$-TOH analogs (naphthyridineol-based tocopherol, $\mathrm{N}-\mathrm{TOH}$ ) show outstanding inhibition of the oxidation of cholesteryl esters in human LDL and secure endogenous $\alpha-\mathrm{TOH}$.<smiles>Cc1nc2c(c(C)c1O)CCC(C(C)(C)C)C2C(C)(C)C</smiles>

Yu et al. [129] study the effect of a peripheral disulfide bridge substituent on the phenolic hydroxyl bond dissociation energy (BDE) and the ionization potential (IP) of 1,8-naphthyridine diol for antioxidant properties of derivatives (106 a-b and107 a-d). Comparing with naphthalene diol, the substituent of a peripheral disulfide bridge group is very proficient in dropping the BDE, while the additions of nitrogen atoms into the naphthalenic ring only slight changes the BDE of $\mathrm{O}-\mathrm{H}$ bond but considerably increase the IP. It is comparable also on consideration of the stereoelectronic behavior of the heterocyclic ring for the $\alpha$-tocopherol, a distinguished antioxidant.<smiles>OC1CCC2CCC(O)CC2C1</smiles>

(106a)<smiles>OC1CCC2CCC(O)C3CCC1C23</smiles>

(106b)<smiles>COc1cnc2c(c1C)=C(C)C(O)CC=2</smiles>

(107a)<smiles>COc1c(O)cnc2ncc(O)c(OC)c12</smiles>

(107b)<smiles>CN(C)c1c(O)cnc2ncc(O)c(N(C)C)c12</smiles>

(107c)<smiles>COc1c(O)cnc2ncc(O)c(O)c12</smiles>

(107d)

\section{Antilipolytic activity}

Aljamal and Badawneh [130] investigate the antilipolytic activity of the new NPTR derivatives (108a and b) on lipolysis induced rat fat cell $\beta$-adrenoceptors by isoprenaline and alprenolol. The NPTR

derivatives substituted with 7-hydroxy-2-(4'-methoxybenzylamine)6-nitro-3-phenyl (108a) and 7-methoxy-N2-(4-methoxybenzyl)-3phenyl-1,8-naphthyridine-2,6-diamine (108b) show the maximum antilipolytic effect.<smiles>COc1ccc(CNC2C=NC3=CC(O)C([N+](=O)[O-])C=C3C=C2C2CCCCC2)cc1</smiles> 


\section{Review articles related to 1, 8-naphthyridine}

Recently, there are significant numbers of reviews which have been published related to the chemistry, synthesis and biological activity of 1, 8-naphthyridine and bioactivities of the 1, 8-naphthyridine metal complexes and multiple activities of 1, 8-naphthyridine [131].

\section{CONCLUSION}

The 1,8-naphthyridine ring is an important pharmacophore in modern drug discovery. Attention has been gradually more given to the synthesis of 1,8-naphthyridine derivatives as a source of new biological agents. The 1,8-naphthyridine derivatives are a resource for further medicinal research. The information gained by various researches has recommended that substituted 1,8-naphthyridines and heterocycles, which are the structural isosteres of nucleotides, allocate them to interact simply with the biopolymers, have pharmacological activity with lower toxicities. Changes in the 1,8-naphthyridine structures have offered high biological activities that have established a start point for the development of novel therapeutic drugs with improved potency and low toxicity. The present review highlights the various synthesized 1,8-naphthyridines (NPTR) and their derivatives showing multiple activities such as analgesic, anti-inflammatory, anticancer, antioxidant, antitubercular, antiviral, antilipolytic antiplatelets, Anticonvulsant and CNS, antiplatelet, acetyl cholinesterase inhibitory, and diuretic activity.

\section{AUTHORS CONTRIBUTIONS}

All the author have contributed equally

\section{CONFLICT OF INTERESTS}

Declared none

\section{REFERENCES}

1. Rani P, Pal DK, Hegde RR, Hashim SR. Synthesis, characterization and pharmacological evaluation of substituted phenoxy acetamide derivatives. Hem Ind 2015;69:405-15.

2. Reissert A. About di-( $\gamma$-amidopropyl) acetic acid (diamino.1.7. heptan methylester.4) and their inner condensations product which octohydro.1.8. naphtyridin. Berichte Der Deutschen Chemischen Gesellschaft 1893;26:2137-44.

3. Ikekawa N. Studies on naphthyridines. I. Synthesis of 1, 6naphthyridine. Chem Pharm Bull 1958;6:263-9.

4. Ikekawa N. Studies on naphthyridines. II. Synthesis of 2, 7naphthyridine. Chem Pharm Bull 1958;6:269-72.

5. Ikekawa N. Studies on naphthyridines. III. Syntheses of 2, 10diazaanthracene and 1, 7-naphthyridine. Chem Pharm Bull 1958;6:401-4.

6. Giacomello G, Gualtieri F, Riccieri FM, Stein ML. Synthesis of 2, 6-naphthyridine. Tetrahedron Lett 1965;6:1117-21.

7. Tan R, Taurins A. Synthesis of 2, 6-naphthyridine and some of its derivatives. Tetrahedron Lett 1965;6:2737-44.

8. Lesher GY, Froelich EJ, Gruett MD, Bailey JH, Brundag RP. 1, 8Naphthyridine derivatives. A new class of chemotherapeutic agents. J Med Chem 1962;5:1063-5.

9. Allen CFH. The naphthyridines. Chem Rev 1950;47:275-305.

10. Litvinov VP, Roman SV, Dyachenko VD. Naphthyridines structure, physicochemical properties and general methods of synthesis. Rus Chem Rev 2000;69:201-20.

11. Litvinov VP. Chemistry and biological activities of 1, 8naphthyridines. Rus Chem Rev 2004;73:637-69.

12. Litvinov VP. Advances in the chemistry of naphthyridines. Adv Heterocycl Chem 2006;91:189-300.

13. Fadda AA, El-Hadidy SA, Elattar KM. Advances in 1, 8naphthyridines chemistry. Synth Comm Rev 2015;45:2765-801.

14. Noravyan AS, Paronikyan EG, Vartanyan SA. Synthesis and pharmacological properties of naphthyridines (review). Pharm Chem J 1985;19:439-48.

15. Shen LL, Pernet AG. Mechanism of inhibition of DNA gyrase by analogues of nalidixic acid: the target of the drugs is DNA. Proc Nat Acad Sci 1985;82:307-11.

16. Muhammad NU, Bature M, Nuhu T, Nafiu A. Fluoroquinolone resistance pattern among the pathogens causing urinary tract infection in a tertiary care hospital in Kanchipuram district, Tamil Nadu, India. Asian J Pharm Clin Res 2017;10:292-4.

17. Vincent J, Venitz J, Teng R, Baris BA, Willavize SA, Polzer RJ, et al. Pharmacokinetics and safety of trovafloxacin in healthy male volunteers following administration of single intravenous doses of the prodrug, alatrofloxacin. J Antimicrob Chemother 1997;39 Suppl B:75-80.

18. Qureshi ZP, Vazquez ES, Monguio RR, Stevenson KB, Szeinbach SL. Market withdrawal of new molecular entities approved in the United States from 1980 to 2009. Pharmacoepidemiol Drug Saf 2011;20:772-7.

19. Mizuki Y, Fujiwara I, Yamaguchi T, Sekine Y. Structure-related inhibitory effect of antimicrobial enoxacin and derivatives on theophylline metabolism by rat liver microsomes. Antimicrob Agents Chemother 1996;40:1875-80.

20. Hall IH, Schwab UE, Ward ES, Ives TJ. Effects of alatrofloxacin, the parental prodrug of trovafloxacin, on phagocytic, antiinflammatory and immunomodulation events of human THP-1 monocytes. Biomed Pharmacother 2003;57:359-65.

21. Paim CS, Nogueira DR, Mitjans M, Lopez DR, Perez JL, Steppe M, et al. Biological safety studies of gemifloxacin mesylate and related substances Photochem Photobiol Sci 2013;12:805-12.

22. Hoch U, Lynch J, Kashimoto YSS, Kajikawa F, Furutani Y, Silverman JA. Voreloxin, formerly SNS-595, has potent activity against a broad panel of cancer cell lines and in vivo tumor models. Cancer Chemother Pharmacol 2009;64:53-65.

23. Evanchik MJ, Allen D, Yoburn JC, Silverman JA, Hoch U. Metabolism of (+)-1,4-dihydro-7-(trans-3-methoxy-4methylamino-1-pyrrolidinyl)-4-oxo-1-(2-thiazol-yl)-1, 8naphthyridine-3-carboxylic acid (Voreloxin; formerly SNS595), a novel replication-dependent DNA-damaging agent. Drug Metab Dispos 2009;37:594-601.

24. Advani RH, Hurwitz HI, Gordon MS, Ebbinghaus SW, Mendelson DS, Wakelee HA, et al. Voreloxin, a first-in-class anticancer quinolone derivative, in relapsed/refractory solid tumors: a report on two dosing schedules. Clin Cancer Res 2010;16:2167-75.

25. Hawtin RE, Stockett DE, Byl JAW, McDowell RS, Tan N, Arkin $\mathrm{MR}$, et al. Voreloxin is an anticancer quinolone derivative that intercalates DNA and poisons topoisomerase II. PLoS One 2010;5:e10186.

26. Scatena CD, Kumer JL, Arbitrario JP, Howlett AR, Hawtin RE, Fox JA, et al. Voreloxin, a first-in-class anticancer quinolone derivative, acts synergistically with cytarabine in vitro and induces bone marrow aplasia in vivo. Cancer Chemother Pharmacol 2010;66:881-8.

27. Freeman C, Keane N, Swords R, Giles F. Vosaroxin: a new valuable tool with the potential to replace anthracyclines in the treatment of AML? Expert Opin Pharmacother 2013;14:1417-27.

28. Pal DK, Mandal M, Senthilkumar GP, Padhiari A. Antibacterial activity of methanol extract of Cuscuta reflexa Roxb. Stem and Corchorus olitorius Linn. Seed Fitoterapia 2006;77:589-91.

29. Mohanta TK, Patra JK, Rath SK, Pal DK, Thatoi HN. Evaluation of antimicrobial activity and phytochemical screening of oils and nuts of Semicarpus anacardium L. f. Sci Res Essays 2007;2:486-90.

30. Nimse SB, Pal DK, Mazumder A, Mazumder R. Synthesis of cinnamanilide derivatives and their antioxidant and

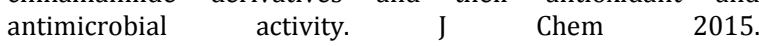
http://dx.doi.org/10.1155/2015/208910

31. Gohil JD, Patel HB, Patel MP. Synthesis and evaluation of new chromene based $[1,8]$ naphthyridines derivatives as potential antimicrobial agents. RSC Adv 2016;6:74726-33.

32. Ghalia S, Thanaa M. An in silico study of novel fluoroquinolones as inhibitors of DNA gyrase of Staphylococcus aureus. Int J Pharm Pharm Sci 2016;8:67-75.

33. Arayne MS, Sultana N, Haroon U, Mesaik MA, Asif M. Synthesis and biological evaluations of enoxacin carboxamide derivatives. Arch Pharm Res 2009;32:967-74.

34. Lv K, Liu ML, Feng LS, Sun LY, Sun YX, Wei ZQ, et al. Synthesis and antibacterial activity of naphthyridone derivatives containing mono/difluoro-methyloxime pyrrolidine scaffolds. Eur J Med Chem 2012;47:619-25. 
35. Feng L, Lv K, Liu M, Wang S, Zhao J, You X, et al. Synthesis and in vitro antibacterial activity of gemifloxacin derivatives containing a substituted benzyloxime moiety. Eur J Med Chem 2012;55:125-36

36. Aggarwal N, Kumar R, Dureja P, Khurana JM. Synthesis of novel nalidixic acid-based 1, 3, 4-thiadiazole and 1, 3, 4-oxadiazole derivatives as potent antibacterial agents. Chem Biol Drug Des 2012;79:384-97.

37. Fadla TA, Radwan AA, Abdelaziz HA, Baseeruddin M, Attiaa MI, Kadi A. Novel Schiff bases of indoline-2, 3-dione and nalidixic acid hydrazide: synthesis, in vitro antimycobacterial and in silico mycobacterium tuberculosis (MTB) DNA gyrase inhibitory activity. Dig J Nanomater Bios 2012;7:327-36.

38. Jalal A, Badawneh M. Synthesis and antitubercular activity of piperidine and morpholine 1, 8-naphthyridine analogues. Int J Pharm Pharm Sci 2016;8:252-7.

39. Kumble D, Geetha MP, Asha FP. Application of metal complexes of Schiff bases as an antimicrobial drug: a review of recent works. Int J Curr Pharm Res 2017;9:27-30.

40. Singh R, Debnath A, Masram DT, Rathore D. Synthesis and biological activities of selected quinolone-metal complexes. Res J Chem Sci 2013;3:83-94.

41. Zakya M, Sayed MYE, Megharbe SME, Taleb SA, Refat MS. Complexes of nalidixic acid with some vital metal ions: synthesis, chemical structure elucidation, and antimicrobial evaluation. Rus J Gen Chem 2013;83:2488-501.

42. Debnath A, Mogha NK, Masram DT. Metal complex of the firstgeneration quinolone antimicrobial drug nalidixic acid: structure and it's a biological evaluation. Appl Biochem Biotechnol 2015;175:2659-67.

43. Saleh MY, Ayoub AI. Synthesis of new derivatives of 2-chloro-3formyl-1, 8-naphthyridine. Eur J Chem 2014;5:475-80.

44. Gao LZ, Xie YS, Li T, Huang WL, Hu GQ. Synthesis and antibacterial activity of novel $[1,2,4]$ triazolo $[3,4-\mathrm{h}][1$, 8]naphthyridine-7-carboxylic acid derivatives. Chin Chem Lett 2015;26:149-51.

45. Acosta P, Butassi E, Insuasty B, Ortiz A, Abonia R, Zacchino SA, et al. Microwave-assisted synthesis of novel pyrazolo[3,4-g][1, 8]naphthyridine-5-amine with potential antifungal and antitumor activity. Molecules 2015;20:8499-520.

46. Donalisio M, Massari S, Argenziano M, Manfroni G, Cagno V, Civra A, et al. Ethyl 1, 8-naphthyridone-3-carboxylates downregulate human papillomavirus-16 E6 and E7 oncogene expression. J Med Chem 2014;57:5649-63.

47. Sakram B, Ashok K, Rambabu S, Sonyanaik B, Ravi D. A novel and efficient synthesis of 3-iodo substituted 1,8-naphthyridines by electrophilic cyclization of 2-amino nicotinaldehyde and their antimicrobial activity. Russ J Gen Chem 2017;87:1794-9.

48. Valadbeigi E, Ghodsi S. Synthesis, and study of some new quinolone derivatives containing a 3-acetyl coumarin for their antibacterial and antifungal activities. Iran J Pharm Res 2017; 16:554-64.

49. Gençer HK, Levent S, Acar U, Ozkay Y, Ilgin S. New 1, 4-dihydro $[1,8]$ naphthyridine derivatives as DNA gyrase inhibitors. Bioorg Med Chem Lett 2017;27:1162-8.

50. Sherlock MH, Kaminski JJ, Tom WC, Lee JF, Wong S, Kreutner W, et al. Antiallergy agents. 1. Substituted 1, 8-naphthyridine$2(1 \mathrm{H})$-ones as inhibitors of SRS-A release. J Med Chem 1988;31:2108-21.

51. Nishikawa $Y$, Shind $\mathrm{T}$, Ishi $\mathrm{K}$, Nakamura $\mathrm{H}$, Kon $\mathrm{T}$, Uno $\mathrm{H}$, et al. Synthesis and antiallergic activity of $\mathrm{N}$-[4-(4'diphenylmethyl-1piperazinyl) butyl-1, 4. dihydro-4-oxo-pyridine-3carboxamides. Chem Pharm Bull 1989;37:1256-9.

52. Saccomanni G, Badawneh M, Adinolfi B, Calderone V, Cavallini $\mathrm{T}$, Ferrarini PL, et al. Synthesis and $\beta$-blocking activity of (R, S)(E)-oxime ethers of 2,3-dihydro-1, 8-naphthyridine and 2,3dihydrothiopyrano [2,3-b] pyridine: identification of $\beta$-3antagonists. Bioorg Med Chem 2003;11:4921-31.

53. Badawneh M, Ferrarini PL, Calderone V, Manera C, Martinotti E, Mori C, et al. Synthesis and evaluation of antihypertensive activity of 1, 8-naphthyridine derivatives. Part X. Eur J Med Chem 2001;36:925-34.
54. Jalal A, Jamal A, Badawneh M. Characterization of the biochemical effects of new 1, 8-naphthyridine derivatives, $\beta$ receptor antagonists, in ventricular myocytes. Arch Pharm Pharm Med Chem 2003;336:285-92.

55. Sannigrahi S, Mazumder UK, Pal DK, Mishra SL. Terpenoids of methanol extract of $C$. infortunatum exhibit anticancer activity against Ehrlich's ascites carcinoma (EAC) in mice. Pharm Biol 2012;50:304-9.

56. Rani P, Pal DK, Hegde RR, Hashim SR. Acetamides: chemotherapeutic agents for inflammation-associated cancers. J Chemother 2016;28:255-65.

57. Sannigrahi S, Mazumder UK, Pal DK, Mondal A, Mishra SL, Roy S. Flavonoids of Enhydra fluctuans exhibit anticancer activity against ehrlich's ascites carcinoma in mice. Nat Prod Comm 2010;5:1239-42.

58. Atanasova M, Ilieva S, Galabov B. QSAR analysis of 1, 4-dihydro4-oxo-1-(2-thiazolyl)-1, 8-naphthyridines with anticancer activity. Eur J Med Chem 2007;42:1184-92.

59. Eweas AF, Khalifa NM, Ismail NS, Al-Omar MA, Soliman AMM. Synthesis, molecular docking of novel 1, 8-naphthyridine derivatives and their cytotoxic activity against HePG2 cell lines. Med Chem Res 2014;23:76-86.

60. Ahmed NS, Alfooty KO, Khalifah SS. An efficient sonochemical synthesis of novel Schiff's bases, thiazolidine, and pyrazolidine incorporating 1, 8-naphthyridine moiety and their cytotoxic activity against HePG2 cell lines. Sci World J 2014;25:587059.

61. Ahmed NS, Alfooty KO, Khalifah SS. Synthesis of 1, 8Naphthyridine derivatives under ultrasound irradiation and cytotoxic activity against HePG2 cell lines. J Chem 2014;1:1-8.

62. Elansary AK, Moneer AA, Kadry HH, Gedawy EM. Synthesis and antitumor activity of certain pyrido [2,3-d ] pyrimidine and 1, 8-naphthyridine derivatives. J Chem Res 2014;38:147-53.

63. Fu L, Feng X, Wang JJ, Xun Z, Hu JD, Zhang JJ, et al. Efficient synthesis and evaluation of antitumor activities of novel functionalized 1, 8naphthyridine derivatives. ACS Comb Sci 2015;17:24-31.

64. Graf M, Gothe Y, Metzler Nolte N, Sünkel K. Cyclometalated iridium(III) and rhodium(III) complexes containing naphthyridine ligands: synthesis, characterization and biological studies. Z Anorg Allg Chem 2017;643:306-10.

65. Jia XD, Wang S, Wang MH, Liu ML, Xia GM, Liu XJ, et al. Synthesis and in vitro antitumor activity of novel naphthyridine derivatives. Chin Chem Lett 2017;28:235-9.

66. Behalo MS, Mele G. Synthesis, and evaluation of pyrido[2,3d]pyrimidine and 1,8-naphthyridine derivatives as potential antitumor agents. J Heterocyclic Chem 2017;54:295-300.

67. Tang Q Duan Y, Wang L, Wang M, O'Yang Y, Wang C, et al. Synthesis and antiproliferative activity of pyrrolo[2,3$b$ ]pyridine derivatives bearing the 1,8-naphthyridine-2-one moiety. Eur J Med Chem 2018;143:266-75.

68. Melha SA. Synthesis and biological evaluation of some novel 1, 8-naphthyridine derivatives. Acta Chim Slov 2017;64:919-30.

69. Pal DK, Mazumder UK. Isolation of compound and studies on CNS depressant activities of Mikania scandens with special emphasis to brain biogenic amines in mice. Indian J Exp Biol 2014;52:1186-94.

70. Negus B, Markocic S. A surgical antiemetic protocolimplementation and evaluation. Acute Pain 2003;5:63-8.

71. Gautam BK, Jindal A, Dhar AK, Mahesh R. Antidepressant-like activity of 2-(4-phenylpiperazine-1-yl)-1, 8-naphthyridine-3carboxylic acid (7a), a 5-HT3 receptor antagonist in behaviour based rodent models: evidence for the involvement of serotonergic system. Pharmacol Biochem Behav 2013;109:91-7.

72. Mahesh R, Dhar AK, Jindal A, Bhatt S. 2-(4-substituted piperazine-1-yl)-1, 8-naphthyridine-3-carboxylic acids: novel $5-\mathrm{HT}_{3}$ receptor antagonists with anxiolytic-like activity in rodent behavioral models. Can J Physiol Pharmacol 2013;91:848-54.

73. Mahesh R, Dhar AK, Jindal A, Bhatt S. Design, synthesis and evaluation of antidepressant activity of novel 2-methoxy 1, 8naphthyridine 3-carboxamides as $5-\mathrm{HT}_{3}$ receptor antagonists. Chem Biol Drug Des 2014;83:583-91.

74. Dhar AK, Mahesh R, Jindal A, Devadoss T. Design, synthesis and pharmacological evaluation of novel 2-(4-substituted 
piperazine-1-yl)-1, 8-naphthyridine-3-carboxylic acids as 5$\mathrm{HT}_{3}$ receptor antagonists for the management of depression. Chem Biol Drug Des 2014;84:721-31.

75. Dhar AK, Mahesh R, Jindal A, Bhatt S. Piperazine analogs of naphthyridine-3-carboxamides and Indole-2-carboxamides: novel $5-\mathrm{HT}_{3}$ receptor antagonists with antidepressant-like activity. Arch Pharm Chem Life Sci 2015;348:34-45.

76. Pal DK, Panda C, Sinhababu S, Dutta A, Bhattacharya S. Evaluation of psychopharmacological effects of petroleum ether extract of Cuscuta reflexa Roxb stem in mice. Acta Polon Pharm Drug Res 2003;60:481-6.

77. Jagerovic N, Fernandez CF, Goya P. CB1 cannabinoid antagonists: structure-activity relationships and potential therapeutic applications. Curr Top Med Chem 2008;8:205-30.

78. Duggan CBM, Debenham JS, Walsh TF, Yan L, Huo P, Wang J, et al. Dihydro-pyrano [2,3-b] pyridines and tetrahydro-1, 8naphthyridines as CB1 receptor inverse agonists: synthesis, SAR, and biological evaluation. Bioorg Med Chem Lett 2010;20:3750-4.

79. Manera C, Benetti V, Castelli MP, Cavallini T, Lazzarotti S, Pibiri $\mathrm{F}$, et al. Design, synthesis, and biological evaluation of new 1, 8naphthyridine-4 $(1 \mathrm{H})$-on-3-carboxamide and quinoline-4 $(1 \mathrm{H})$ on-3-carboxamide derivatives as CB2 selective agonists. J Med Chem 2006;49:5947-57.

80. Manera C, Saccomanni G, Malfitano AM, Bertini S, Castelli F, Laezza C, et al. Rational design, synthesis and anti-proliferative properties of new CB2 selective cannabinoid receptor ligands: an investigation of the 1, 8-naphthyridine-2 $(1 \mathrm{H})$-one scaffold. Eur J Med Chem 2012;52:284-94.

81. Lucchesi V, Hurst DP, Shore DM, Bertini S, Ehrmann BM, Allara $\mathrm{M}$, et al. CB2-selective cannabinoid receptor ligands: synthesis, pharmacological evaluation, and molecular modeling investigation of 1, 8-naphthyridine-2 (1H)-one-3carboxamides. J Med Chem 2014;57:8777-91.

82. Manera C, Saccomanni G, Adinolfi B, Benetti V, Ligresti A, Cascio $\mathrm{MG}$, et al. Rational design, synthesis, and pharmacological properties of new 1, 8-naphthyridine-2(1H)-on-3-carboxamide derivatives as highly selective cannabinoid-2 receptor agonists. J Med Chem 2009;52:3644-51.

83. Saccomanni G, Pascali G, Carlo SD, Panetta D, Simone MD, Bertini S, et al. Design, synthesis and preliminary evaluation of [18]F-labelled 1, 8-naphthyridine and quinoline-2-one-3carboxamide derivatives for PET imaging of CB2 cannabinoid receptor. Bioorg Med Chem Lett 2015;25:2532-5.

84. Manera C, Malfitano AM, Parkkari T, Lucchesi V, Carpi S, Fogli S, et al. New quinolone and 1, 8-naphthyridine-3-carboxamides as selective CB2 receptor agonists with anticancer and immunomodulatory activity. Eur J Med Chem 2015;97:10-8.

85. Malfitano AM, Laezza C, Saccomanni G, Tuccinardi T, Manera C, Martinelli $\mathrm{A}$, et al. Immune-modulation and properties of absorption and blood brain barrier permeability of 1, 8naphthyridine derivatives. J Neuroimmune Pharmacol 2013;8:1077-86.

86. Malfitano AM, Laezza C, Alessandro AD, Procaccini C, Saccomanni G, Tuccinardi T, et al. Effects on immune cells of a new 1, 8-naphthyridine-2-one derivative and its analogues as selective CB2 agonists: implications in multiple sclerosis. PLOS One 2013;8:1-9.

87. Malfitano AM, Laezza C, Bertini S, Marasco D, Tuccinardi T, Bifulco $\mathrm{M}$, et al. Immunomodulatory properties of 1,2-dihydro4-hydroxy-2-oxo-1,8-naphthyridine-3-carboxamide derivative VL15. Biochimie 2017;135:173-80.

88. Pommier Y, Johnson AA, Marchand C. Integrase inhibitors to treat HIV/AIDS. Nat Rev Drug Disc 2005;4:236-48.

89. Serrao E, Odde S, Ramkumar K, Neamati N. Raltegravir, elvitegravir, and metoogravir: the birth of "me-too" HIV-1 integrase inhibitors. Retrovirology 2009;6:33.

90. Nagasawa JY, Song J, Chen H, Kim HW, Blazel J, Ouk S, et al. 6benzylamino 4-oxo-1,4-dihydro-1, 8-naphthyridines and 4-oxo1,4-dihydroquinolines as HIV integrase inhibitors. Bioorg Med Chem Lett 2011;21:760-3.

91. Zhao XZ, Smith SJ, Metifiot M, Johnson BC, Marchand C, Pommier $\mathrm{P}$, et al. Bicyclic 1-hydroxy-2-oxo-1,2- dihydropyridine-3-carboxamide-containing HIV-1 integrase inhibitors having high antiviral potency against cells harboring raltegravir-resistant integrase mutants. J Med Chem 2014;57:1573-82.

92. Zhao XZ, Smith SJ, Metifiot M, Marchand C, Boyer PL, Pommier Y, et al. 4-Amino-1-hydroxy-2-oxo-1, 8-naphthyridine-containing compounds having high potency against raltegravir-resistant integrase mutants of HIV-1. J Med Chem 2014;57:5190-202.

93. Massari S, Daelemans D, Barreca ML, Knezevich A, Sabatini S, Cecchetti V, et al. A 1, 8-naphthyridone derivative targets the HIV-1 tat-mediated transcription and potently inhibits the HIV1 replication. J Med Chem 2010;53:641-8.

94. Tabarrini O, Massari S, Sancineto L, Daelemans D, Sabatini S, Manfroni G, et al. Structural investigation of the naphthyridone scaffold: identification of a 1,6-naphthyridone derivative with potent and selective anti-HIV activity. Chem Med Chem 2011;6:1249-57.

95. Rani P, Pal DK, Hegde RR, Hashim SR. Anticancer, antiinflammatory, analgesic activities of synthesized 2-(substituted phenoxy) acetamide derivatives. Biomed Int 2014;386473:1-9.

96. Rani P, Pal DK, Hegde RR, Hashim SR. Leuckart synthesis and studies on anticancer, anti-inflammatory and analgesic activities of novel acetamide derivatives. Anticancer Agents Med Chem 2016;16:898-906.

97. Pal DK, Sannigrahi S, Mazumder UK. Analgesic and anticonvulsant effects of isolated saponin from the leaves of Clerodendrum infortunatum Linn. in mice. Indian J Exp Biol 2009; 47:743-7.

98. Sun XY, Wei CX, Chai KY, Piao HR, Quan ZS. Synthesis and antiinflammatory activity evaluation of novel 7-alkoxy-1-amino4,5-dihydro[1,2,4]triazole[4,3-a]quinolines. Arch Pharm Chem Life Sci 2008;341:288-93.

99. Madaan A, Kumar V, Verma R, Singh AT, Jain SK, Jaggi M. Antiinflammatory activity of a naphthyridine derivative (7-chloro6-fluoro-N-(2-hydroxy-3-oxo-1-phenyl-3-(phenylamino) propyl)-4-oxo-1-(prop-2-yn-1-yl)-1, 4-dihydro-1, 8naphthyridine-3-carboxamide) possessing in vitro anticancer potential. Int Immunopharmacol 2013;15:606-13.

100. Braccio MD, Grossi G, Alfei S, Ballabeni V, Tognolini M, Flammini L, et al. 1, 8-Naphthyridines IX. Potent antiinflammatory and/or analgesic activity of a new group of substituted 5-amino $[1,2,4]$ triazolo $[4,3-a][1,8]$ naphthyridine-6-carboxamides, of some their mannich base derivatives and of one novel substituted 5-amino-10-oxo10Hpyrimido $[1,2$-a] $[1,8]$ naphthyridine-6-carboxamide derivative. Eur J Med Chem 2014;86:394-405.

101. Jacobson KA, Gao ZG. Adenosine receptors as therapeutic targets. Nat Rev Drug Discovery 2006;5:247-64

102. Manera C, Betti L, Cavallini T, Giannaccini G, Martinelli A, Ortore G, et al. 1, 8-Naphthyridine-4-one derivatives as new ligands of $\mathrm{A}_{2} \mathrm{~A}$ adenosine receptors, Bioorg Med Chem Lett 2015;15:4604-10.

103. Ferrarini PL, Mori C, Manera C, Martinelli A, Mori F, Saccomanni $\mathrm{G}$, et al. A novel class of highly potent and selective A1 adenosine antagonists: structure-affinity profile of a series of 1 , 8naphthyridine derivatives. J Med Chem 2000;43:2814-23.

104. Sandhya A, Gomathi K. Alzheimer's disease therapeutic approaches. Asian J Pharm Clin Res 2018;11:17-24.

105. Silva D, Chioua M, Samadi A, Carreiras MC, Jimeno ML, Mendes E, et al. Synthesis and pharmacological assessment of diversely substituted pyrazolo $[3,4-\mathrm{b}]$ quinoline, and benzo [b] pyrazolo [4, 3-g] [1, 8] naphthyridine derivatives. Eur J Med Chem 2011; 46:4676-81

106. Klenc J, Lipowska M, Taylor AT. Identification of lead compounds for [99 $]^{\mathrm{m} T c}$ and [18]F GPR91 radiotracers. Bioorg Med Chem Lett 2015;25:2335-9.

107. Chandra P, Sachan N, Pal DK. Protective effect of Dalbergia sissoo Roxb. Ex Dc (family Fabaceae) leaves against experimentally induced diarrhea and peristalsis in mice. Toxicol Ind Health 2013;20:1-7.

108. Sacchan N, Chandra P, Pal DK. Evaluation of gastroprotective potential of Dalbergia sissoo (family: Fabaceae) in experimental rats. Int J Indigen Med Plants 2015;48:1778-85. 
109. Sacchan N, Chandra P, Pal DK. Assessment of the gastroprotective potential of Dalonix revia (Boj-Ex Sooa) Raf. Against ethanol and cold rextrin stressed-induced ulcer in rats. Trop J Pharm Res 2015;14:1063-70.

110. Santilli AA, Scotese AC, Bauer RF, Bell SC. 2-0xo-1, 8naphthyridine-3-carboxylic acid derivatives with potent gastric antisecretory properties. J Med Chem 1987;30:2270-7.

111. Sekhar KVGC, Rao VS, Conrad WD, Reddy AS, Brust P, Kumar MMK. Design, synthesis, and preliminary in vitro and in vivo pharmacological evaluation of $2-\{4-[4-(2,5-$ disubstitutedthiazol-4-yl) phenylethyl] piperazine-1-yl\}-1, 8naphthyridine-3-carbonitriles as atypical antipsychotic agents. J Enzyme Inhib Med Chem 2011;26:561-8.

112. Ferrarini PL, Mori C, Badawneh M, Franconi F, Manera C, Miceli $\mathrm{M}$, et al. Synthesis and antiplatelet activity of some 3-phenyl-1, 8-naphthyridine derivatives. Il Farmaco 2000;55:603-10.

113. Ferrarini PL, Badawneh M, Franconi F, Manera C, Miceli M, Mori C, et al. Synthesis and antiplatelet activity of some 2, 7-di ( $N$-cycloamino)-3-phenyl-1, 8-naphthyridine derivatives. Il Farmaco 2001;56:311-8

114. Naik TR, Naik HS, Naik HR, Bindu PJ, Harish BG, Krishna V. Synthesis, DNA binding, docking and photocleavage studies of novel benzo $[b][1,8]$ naphthyridines. Med Chem 2009;5:411-8.

115. Dhamodharan V, Harikrishna S, Jagadeeswaran C, Halder K, Pradeepkumar PI. Selective G-quadruplex DNA stabilizing agents based on bisquinolinium and bispyridinium derivatives of 1, 8-naphthyridine. J Org Chem 2012;77:229-42.

116. Ban H, Muraoka M, Ioriya K, Ohashi N. Synthesis and biological activity of novel 4-phenyl-1, 8-naphthyridine-2 $(1 H)$-on-3-yl ureas: Potent acyl-CoA: cholesterol acyltransferase inhibitor with improved aqueous solubility. Bioorg Med Chem Lett 2006;16:44-8.

117. Kanouni T, Dong Q Abelovski B, Wallace MB. Synthetic approaches to 1, 8-naphthyridine-2, 5-dione compounds. Tetrahedron Lett 2011;52:477-9.

118. Takayama K, Iwata M, Hisamichi H, Okamoto Y, Aoki M, Niwa A. Synthetic studies on selective type 4 phosphodiesterase (PDE 4) inhibitors. 1. structure-activity relationships and pharmacological evaluation of 1, 8-naphthyridine-2(1H)-one derivatives. Chem Pharm Bull 2002;50:1050-9.

119. Rodan SB, Rodan GA. Integrin function in osteoclasts. J Endocrinol 1997;154:S47-56.

120. Hartner FW, Hsiao Y, Eng KK, Rivera NR, Palucki M, Tan L, et al. Methods for the synthesis of $5,6,7,8$-Tetrahydro-1, 8naphthyridine fragments for $\alpha_{v} \beta_{3}$ integrin antagonists. J Org Chem 2004;69:8723-30.

121. Nagarajan SR, Lu HF, Gasiecki AF, Khanna IK, Parikh MD, Desai $\mathrm{BN}$, et al. Discovery of $+(2-\{4-[2-(5,6,7,8$-tetrahydro- 1 , 8naphthyridine-2-yl) ethoxy] phenyl\}-cyclopropyl) acetic acid as potent and selective $\alpha_{v} \beta_{3}$ inhibitor: design, synthesis, and optimization. Bioorg Med Chem 2007;15:3390-412.

122. Al-Salem HS, Hegazy GH, El-Taher KE, El-Messery SM, Al-Obaid AM, El-Subbagh HI. Synthesis, anticonvulsant activity and molecular modeling study of some new hydrazinecarbothioamide, benzenesulfonohydrazide, and phenacylacetohydrazide analogues of $4(3 \mathrm{H})$-quinazolinone. Bioorg Med Chem Lett 2015;25:1490-9.

123. Stuk TL, Assink BK, Bates RC, Erdman DT, Fedij V, Jennings SM, et al. An efficient and cost-effective synthesis of pagoclone. Org Proc Res Dev 2003; 7:851-5.

124. Lorrio S, Romero A, Gonzalez Lafuente L, Lajarin Cuesta R, Martinez Sanz FJ, Estrada M, et al. PP2A ligand ITH12246 protects against memory impairment and focal cerebral ischemia in mice. ACS Chem Neurosci 2013;4:1267-77.

125. Wang $\mathrm{H}$, Wang $\mathrm{S}$, Cheng $\mathrm{L}$, Chen L, Wang Y, Qing J, et al. Discovery of imidazo $[1,2-\alpha][1,8]$ naphthyridine derivatives as a potential HCV entry inhibitor. ACS Med Chem Lett 2015;6:977-81.

126. Nimse SB, Pal DK. Free radicals, natural antioxidants, and their reaction mechanisms. RSC Adv 2015;5:27986-8006.

127. Sannigrahi S, Mazumder UK, Pal DK, Parida S, Jain S Antioxidant potential of crude extract and its different fraction of methanol extract of Enhydra fluctuans Lour. Iranian J Pharm Res 2010;9:75-82.

128. Nam TG, Rector CL, Kim HY, Sonnen AF, Meyer R, Nau WM, et al. Tetrahydro-1, 8-naphthyridineol analogues of $\alpha$-Tocopherol as antioxidants in lipid membranes and low-density lipoproteins. J Am Chem Soc 2007;129:10211-9.

129. Yu A, Wang J, Xue X, Wang Y. Theoretical study of the peripheral disulfide bridge substituent effects on the antioxidant properties of naphthyridine diol derivatives. J Phy Chem A 2010;114:1008-16.

130. Aljamal JA, Badawneh M. Antilipolytic effects of 1,8naphthyridine derivatives $\beta$-adrenoceptor antagonists in rat white adipocytes. Chem Biol Drug Des 2017;90:119-27.

131. Madaan A, Verma R, Kumar V, Singh AT, Jain SK, Jaggi M. 8Naphthyridine derivatives: a review of multiple biological activities. Arch Pharm Chem Life Sci 2015;348:1-24.

132. Shimamoto T, Inoue H, Hayashi Y. 1-Cycloalkyl-1,8naphthyridine-4-one derivative as type iv phosphodiesterase inhibitor. US patent 6331548; 2001.

133. Bachand B, Nguyen-Ba N, Siddiqui A. Antiviral methods using $[1,8]$ naphthyridine derivatives. US patent $6340690 ; 2002$.

134. Vaillancourt VA, Thorarensen A. 4-0xo-1,4 dihydro[1,8]naphthyridine 3-carboxamides as antiviral agents. US patent 6451811; 2002.

135. Yamin W, David EG, Qingjie L, Sidney XL, William HB, Donglei L, et al. 1, 8-Naphthyridine derivatives as antidiabetics. WIPO patent 03/027112; 2003.

136. Bachand B, Nguyen Ba N, Siddiqui A. 1,8-Naphthyridine derivatives having antiviral activity. US patent US 6605614 2003.

137. Yamin W, William B, David G, Qingjie L, Sidney L, Donglei L, et al. 1,8-Naphthyridine derivatives and their use to treat diabetes and related disorders. US patent 20040014751A1; 2001.

138. Muraoka M, Ohnuma S, Ban H. 1, 2-Dihydro-2-oxo-1, 8naphthyridine derivative. US patent 7067528B2; 2006.

139. Yamin W, William B, David G, Qingjie L, Sidney L, Donglei L, et al. 1,8-Naphthyridine derivatives and their use to treat diabetes and related disorders. US patent 7109196B2; 2006.

140. Jeffrey PW, Michael S, Terence M. Heterocyclic substituted 1,4dihydro-4ox9-1,8-naphthyridine analogs. US patent 7163948 B2; 2007.

141. Deodialsingh G, Jeffrey JH, Shankaran K. Novel 1,8naphthyridine compounds. US patent 20100056563A1; 2010.

142. Fabio R, Di F, Micheli Y. 1,8-Naphthyridines as CRF antagonists. EP patent EP1695974B1; 2010

143. Miller WH, Newlander KA, Seefeld MA, Uzinskas IN, DeWolf Jr WE, Jakas DR. Fab I inhibitors. US patent US7790716B2; 2010.

144. Rainer H. 1,6-Naphthyridine and 1,8-naphthyridine derivatives and their use to treat diabetes and related disorders. WIPO patent W02005091857A3; 2006

145. Adelman DC, Evanchik MJ, Sudhakar A, Jacobs JW, Silverman JA. 1,8-Naphthyridine compounds for the treatment of cancer. US patent 8124773B2; 2012.

146. Jonczyk A, Dorsch D, Zenke F, Amendt C. Hetarylaminonaphthyridines. US patent US 2012/0316166A1 2012.

147. Alam A, Biscarrat S, Blanc I, Bono F, Duclos O, McCort G. Derivatives of 7-alkynyl-1,8-naphthyridones, preparation method thereof and 2011'use of same in therapeutics. US Patent US 8470847B2; 2013.

148. Adelman DC, Evanchik MJ, Sudhakar A, Jacobs JW, Silverman JA. 1,8-Naphthyridine compounds for the treatment of cancer. US Patent US 8765954B2; 2014.

149. Jonczyk A, Dorsch D, Zenke F, Amendt C. Hetaryl[1,8]naphthyridine derivatives. US patent US 8912216; 2012.

150. Choi DR, Yang J, Yoon SH, Pyun SJ, Kim SH, Seong SK, et al. R-7(3-aminomethyl-4-methoxyimino-3-methyl-pyrrolidine-1-yl)1-cyclopropyl-6--fluoro-4-oxo-1,4-dihydo-[1,8]naphthyridine3 -carboxylic acid and an l-aspartic acid salt, the process for the preparation thereof and a pharmaceutical composition comprising the same for antimicrobial. US patent US 8952164B2; 2015. 
151. Glenn M. Methods of using (+)-1,4-dihydro-7-[(3s,4s)-3-methoxy4-(methylamino)-1-pyrrolidinyl]-4-ox-o-1-(2-thiazolyl)-1,8- naphthyridine-3-carboxylic acid for treatment of antecedent hematologic disorders. US patent 20150250775; 2015. 